\title{
Effect of cold storage temperature on quality of the parasitoid, Trichogrammatoidea bactrae Nagaraja (Hymenoptera: Trichogrammatidae)
}

\author{
Hend O. Mohamed ${ }^{*}$ (D) and A. H. El-Heneidy
}

\begin{abstract}
This study was designed to find out the optimum cold storage temperature $\left(4,7\right.$, and $\left.10{ }^{\circ} \mathrm{C}\right)$ and storage period $(1-$ 16 weeks) of 3 different immature developmental stages $(2,4,6$ days post parasitism) of the egg parasitoid, Trichogrammatoidea bactrae Nagaraja (Hymenoptera: Trichogrammatidae) to produce high-quality individuals to be utilized. Also, the effects of cold storage on parasitoids' fitness in terms of parasitism percentage, developmental period, adults' emergence percentage, female percentage, and longevity (fed and un-fed) of parents and $F_{1}$ progeny were investigated. The obtained results revealed that $T$. bactrae larvae (2-day post parasitism) could be stored for at least 7 weeks at $10^{\circ} \mathrm{C}$, with least changes in their fitness in both the parents and $\mathrm{F}_{1}$ progeny, followed by $7{ }^{\circ} \mathrm{C}$, whereas storage at $4^{\circ} \mathrm{C}$ was the fatal temperature in this early stage of parasitoid with a maximum mortality rate that extended to the next generation $\left(F_{1}\right)$. Furthermore, female biased sex ratios were observed at all storage temperatures in the parental and $F_{1}$ generations but with different values. After a cold exposure of pre- and pupal stages $\left(4,6\right.$ days post parasitism) of the parasitoid at $7{ }^{\circ} \mathrm{C}$, adults' emergence percentage in the parents was low, but the biological performance in progeny was great. In addition, these late stages could be stored for a short period up to 4 weeks at $10^{\circ} \mathrm{C}$ with highest performances in both generations, followed by $7^{\circ} \mathrm{C}$. Ten degrees Celsius proved to be the most suitable storage temperature at different parasitoid ages (larvae, pre-pupae, and pupae). Only the larval stage could continue up to 16 weeks of cold storage, and hence, it can be recommended for a short- and/or a long-term storage period.
\end{abstract}

Keywords: Trichogrammatoidea bactrae, Cold storage, Parasitism percentage, Developmental period, Adults' emergence percentage, Sex ratio, Longevity

\section{Background}

Biological control is a worldwide major component used in pest management for the regulation of pest populations, using natural enemies (DeBach and Rosen 1991; and Bale et al. 2008). Parasitic wasps of the genera, Trichogramma and Trichogrammatoidea, are among the most common and effective bio-control agents because of their capability to attack eggs of many economical

\footnotetext{
* Correspondence: honos_1@yahoo.com

Biological Control Research Department, Plant Protection Research Institute, Agricultural Research Center, Giza, Egypt
}

(c) The Author(s). 2020 Open Access This article is licensed under a Creative Commons Attribution 4.0 International License, which permits use, sharing, adaptation, distribution and reproduction in any medium or format, as long as you give appropriate credit to the original author(s) and the source, provide a link to the Creative Commons licence, and indicate if changes were made. The images or other third party material in this article are included in the article's Creative Commons licence, unless indicated otherwise in a credit line to the material. If material is not included in the article's Creative Commons licence and your intended use is not permitted by statutory regulation or exceeds the permitted use, you will need to obtain permission directly from the copyright holder. To view a copy of this licence, visit http://creativecommons.org/licenses/by/4.0/.

pests in different agricultural crops (Hutchison et al. 1990). The egg-parasitoid, Trichogrammatoidea bactrae Nagaraja (Hymenoptera: Trichogrammatidae), was described first from lepidopterous pest specimens collected from rice (Oryza sativa L.), cabbage (Brassica oleracea Var.), and corn (Zea mays L.) (Nagaraja 1978). The main problem of releasing the parasitic wasps as biological control agents is field requirements and high cost of their mass production for augmentative releases at the suitable time whenever required (Tezze and Botto 2004; Ayvaz et al. 2008; and Lü et al. 2019). To overcome 
these problems, improving an effective cold storage technique is an important tool for increasing and mass producing high-quality individuals when needed (Tezze and Botto 2004). Prolonged cold storage periods of the parasitoids during their immature stages can cause physiological malfunctions (Colinet and Boivin 2011), depletion of energy reserves (Chen et al. 2008), and morphological alterations as deformations of reproductive organs (Denlinger and Lee 1998), a reduction in body size (Rundle et al. 2004), wing's distortion (Dutton and Bigler 1995; and Tezze and Botto 2004), and alteration on antennal structure (Pintureau and Daumal 1995). Otherwise, low temperature exposure can negatively affect the fitness of produced individuals and offspring such as causing a reduction in adults' emergence (Özder and Sağlam 2004; Yilmaz et al. 2007; and Nadeem et al. 2010), a decrease in longevity (Rundle et al. 2004; Yilmaz et al. 2007; and Gharbi 2014), fecundity (Colinet and Boivin 2011 and Gharbi 2014), more males production (Chen et al. 2008), and a reduction in parasitoid's mobility (Tezze and Botto 2004 and Ayvaz et al. 2008). Worldwide, several researches on cold storage of different Trichogramma species have been studied extensively (Rundle et al. 2004; Özder and Sağlam 2004; Kim et al. 2009; Nadeem et al. 2010; Gharbi 2014; Bhargavi and Naik 2015; RahimiKaldeh et al. 2017; Vigneswaran et al. 2017; Ghosh and Ballal 2018; Lü et al. 2019; and Abbes et al. 2020).

Based on the authors' knowledge, few instances were pointed on the cold tolerance of different developmental stages of the Trichogrammatoidea species. Meanwhile, this study aimed to evaluate the effects of short- and long-term cold storages on the fitness of the produced T. bactrae population for mass rearing programs.

\section{Materials and methods}

\section{Host rearing}

The Angoumois grain moth, Sitotroga cerealella (Oliver) (Lepidoptera: Gelechiidae) stock culture, was reared on wheat grains, Triticum aestivum L. (Sedes1), that obtained from the laboratory colonies at the mass rearing unit of Trichogramma, Plant Protection Research Institute, Agricultural Research Center (ARC), in Assiut. S. cerealella eggs were used as a factious host for the studied parasitoid.

\section{Parasitoid rearing}

T. bactrae, used in this study, was imported for the first time from Australia in 1992 as an egg-parasitoid for control of the pink bollworm (Lepidoptera: Gelechiidae) by Dr. A. H. El-Heneidy (ARC, Egypt) through a collaborative project with American Universities. This parasitoid species was established under Egyptian environmental conditions and was mass reared at the Center of Bioorganic Agricultural Services (CBAS), in Aswan. Freshly laid eggs of $S$. cerealella, glued onto a piece of white cardboard by a fine gum film, were introduced into plastic jars (1L capacity) harboring newly emerged $T$. bactrae wasps for $24 \mathrm{~h}$ to avoid super-parasitism. The parasitism was performed under standard rearing conditions of $25 \pm 1{ }^{\circ} \mathrm{C}$ and $>60 \% \mathrm{RH}$ with 14L: 10D cycle (Nadeem et al. 2010). Parasitoid adults were provided by sugar solution (10\%) for nutrition. After $24 \mathrm{~h}$ of exposure to the parasitoid, parasitized host egg cards (Trichocards) were collected and maintained in clean jars.

\section{Experimental design for cold storage}

Once the Tricho-cards reached 2, 4, and 6 days post parasitism, thus providing 3 different developmental stages of the parasitoid (larvae, pre-pupae, and oldpupae). Samples from each age consisted of a piece of cardboard strip holding approximately $350 \pm 50$ parasitized eggs were placed in 250-ml plastic jars, then maintained at 3 different incubators, and stored at 3 low temperatures $\left(4,7\right.$, and $10 \pm 1{ }^{\circ} \mathrm{C} ;>60 \% \mathrm{RH}$ and full darkness) for various storage durations (1-16 weeks) until parasitoid adult emergence percentage reached a very low level $\leq 10 \%$. For each treatment (storage period), 12 replicates were used. After each storage duration, parasitoid strips were removed from the storage incubator to the standard rearing room conditions as mentioned above. Control (un-stored card) was also kept at the standard rearing room conditions for comparison.

\section{Effect of cold storage on the parasitoids' fitness}

Effect of low temperature exposure for different periods on the fitness of the egg-parasitoid, T. bactrae (the parents), was assessed by measuring the following biological variables at each immature developmental stage compared to the control: parasitism percentage (no. of parasitized eggs (blackened eggs)/ total no. of egg's exposed); developmental time (the time till adult emergence for control), for treated groups as (the time between the end of cold storage till adult emergence); adult emergence rate (no. of emerged adults/ no. of parasitized eggs); and females' ratio was determined by examining dead adults under a stereomicroscope (no. of emerged adult females/ total individuals). Longevity of adults was recorded daily from the time of adult emerged till mortality (for fed and un-fed adults). For the parasitoid nutrition, few droplets of sugar solution $(10 \%)$ were provided daily until the wasps died.

The $F_{1}$ progeny obtained from the cold stored parental generation was also counted at the aforementioned rearing conditions. Each sample consisted of a piece of a cardboard strip, with approximately $250 \pm 50$ eggs of S. cerealella exposed for $24 \mathrm{~h}$ to the produced parasitoid from cold storage. Parasitism percentage, adult emergence rate, female ratio, and longevity of fed and un-fed adults were calculated as the same way as described above for the parental generation. 


\section{Statistical analysis}

Obtained data were subjected to one- and two-way analysis of variance (ANOVA) by the Advanced Statistical Analysis Package (ASAP) ${ }^{\mathrm{R}}$. Data were arcsine $\sqrt{\mathrm{x}}$ transformed before analysis to meet normality. Means were separated, using the least significant difference (LSD) at $P \leq 0.05$ level. All calculations and graphs were used by the Microsoft Excel ${ }^{\circ}$ software according to Fowler et al. (1998).

\section{Results and discussion \\ Cold storage of parasitoid larvae (2-day post parasitism) Parental generation}

Parasitism percentage Cold storage at $4{ }^{\circ} \mathrm{C}$ reduced drastically the parasitism rates compared with the other temperatures $\left(7\right.$ and $10{ }^{\circ} \mathrm{C}$ ) and control (Table 1 (a)). The parasitism stopped at $4{ }^{\circ} \mathrm{C}$ after 6 weeks of storage only, while at $7{ }^{\circ} \mathrm{C}$, it continued for 9 weeks. In case of $10{ }^{\circ} \mathrm{C}$, it developed and extended to 16 weeks. The 2-way ANOVA revealed that there were significant differences for the effect of temperature (A), storage period (B), and the effect of storage period-temperature interaction $(\mathrm{A} \times$ B) at $P \leq 0.05\left(\operatorname{LSD}_{(\mathrm{A})}=8.321, F=89.945 ; \mathrm{LSD}_{(\mathrm{B})}=\right.$ $14.412, F=1.284$; and $\left.\operatorname{LSD}_{(\mathrm{A} \times \mathrm{B})}=24.692, F=9.094\right)$.
Developmental period Developmental period of the parasitoid increased significantly $(P<0.0001)$ with extending the storage period at $4{ }^{\circ} \mathrm{C}$ than in the control and the two other temperatures (Table 1 (b)). No difference between storage at $7{ }^{\circ} \mathrm{C}$ and control up to 4 weeks; then, the duration increased significantly $(P=0.000)$. On contrary, at $10{ }^{\circ} \mathrm{C}$, only the first 2 weeks of storage was almost similar to control, and afterwards the period decreased significantly $(P=0.000)$. There were significant variations for the main effects of temperature $(A)$, storage period $(\mathrm{B})$, and their interaction $(\mathrm{A} \times \mathrm{B})$ at $P \leq 0.05$ $\left(\mathrm{LSD}_{(\mathrm{A})}=0.113, F=2497.415 ; \mathrm{LSD}_{(\mathrm{B})}=0.196, F=\right.$ 746.871; and $\left.\operatorname{LSD}_{(\mathrm{A} \times \mathrm{B})}=0.339, F=911.762\right)$.

Adults' emergence percentage The effect of cold storage on the adult emergence percentage decreased significantly at all storage periods $(P=0.000)$ than the control (Table 2$)$. The percentage increased with the increase of low temperature but decreased with increasing the cold exposure period. Subsequently, it increases the proportion of deformed adults. There were significant variations for the effect of temperature (A), storage period (B), and their interaction (A $\times \mathrm{B})$ at $P \leq 0.05\left(\operatorname{LSD}_{(\mathrm{A})}=9.429, F=16.908 ; \operatorname{LSD}_{(\mathrm{B})}=\right.$ $16.332, F=1.946$; and $\left.\mathrm{LSD}_{(\mathrm{A} \times \mathrm{B})}=28.288, F=6.048\right)$.

Table 1 Percentages of parasitism and developmental period of Trichogrammatoidea bactrae in parental generation during storage of parasitoid larvae at different low temperatures

\begin{tabular}{|c|c|c|c|c|c|c|c|c|c|c|c|c|c|c|c|c|}
\hline \multicolumn{17}{|c|}{ (a) Parasitism \% } \\
\hline \multirow{2}{*}{ Temp. } & \multicolumn{16}{|c|}{ Duration (weeks) } \\
\hline & 1 & 2 & 3 & 4 & 5 & 6 & 7 & 8 & 9 & 10 & 11 & 12 & 13 & 14 & 15 & 16 \\
\hline $\begin{array}{l}4 \\
{ }^{\circ} \mathrm{C}\end{array}$ & $\begin{array}{l}74.19 \pm \\
2.65 \mathrm{BC}\end{array}$ & $\begin{array}{l}30.15 \pm \\
1.49 \mathrm{Cb}\end{array}$ & $\begin{array}{l}11.08 \\
\pm \\
1.38 \mathrm{Db}\end{array}$ & $\begin{array}{l}3.93 \pm \\
1.18 \mathrm{~Eb}\end{array}$ & $\begin{array}{l}2.40 \pm \\
0.22 \mathrm{FC}\end{array}$ & $\begin{array}{l}1.30 \pm \\
0.14 G c\end{array}$ & - & - & - & - & - & - & - & - & - & - \\
\hline $\begin{array}{l}7 \\
{ }^{\circ} \mathrm{C}\end{array}$ & $\begin{array}{l}86.65 \pm \\
1.02 \mathrm{Aa}\end{array}$ & $\begin{array}{l}89.25 \pm \\
1.16 \mathrm{Aa}\end{array}$ & $\begin{array}{l}87.41 \\
\pm \\
0.90 \mathrm{Aa}\end{array}$ & $\begin{array}{l}86.73 \\
\pm \\
0.78 \mathrm{Aa}\end{array}$ & $\begin{array}{l}84.09 \pm \\
1.17 \mathrm{ABb}\end{array}$ & $\begin{array}{l}80.68 \pm \\
1.38 \mathrm{CDb}\end{array}$ & $\begin{array}{l}81.91 \pm \\
1.61 \mathrm{BCa}\end{array}$ & $\begin{array}{l}78.14 \\
\pm \\
1.34 \mathrm{Db}\end{array}$ & $\begin{array}{l}77.64 \pm \\
1.14 \mathrm{Da}\end{array}$ & - & - & - & - & - & - & - \\
\hline $\begin{array}{l}10 \\
{ }^{\circ} \mathrm{C}\end{array}$ & $\begin{array}{l}81.91 \pm \\
1.26 \mathrm{BCb}\end{array}$ & $\begin{array}{l}84.34 \pm \\
3.68 \mathrm{ABa}\end{array}$ & $\begin{array}{l}91.55 \\
\pm \\
1.01 \mathrm{Aa}\end{array}$ & $\begin{array}{l}90.16 \\
\pm \\
1.11 \mathrm{Aa}\end{array}$ & $\begin{array}{l}92.08 \pm \\
1.15 \mathrm{Aa}\end{array}$ & $\begin{array}{l}89.13 \pm \\
1.15 \mathrm{Aa}\end{array}$ & $\begin{array}{l}80.3 \pm \\
2.44 \mathrm{Ca}\end{array}$ & $\begin{array}{l}83.82 \\
\pm \\
2.25 \mathrm{Ba}\end{array}$ & $\begin{array}{l}81.85 \pm \\
1.79 B C a\end{array}$ & $\begin{array}{l}91.34 \\
\pm \\
1.43 \mathrm{~A}\end{array}$ & $\begin{array}{l}91.97 \\
\pm \\
0.91 \mathrm{~A}\end{array}$ & $\begin{array}{l}92.84 \\
\pm \\
0.54 \mathrm{~A}\end{array}$ & $\begin{array}{l}92.39 \\
\pm \\
1.0 \mathrm{~A}\end{array}$ & $\begin{array}{l}89.22 \\
\pm \\
1.37 \mathrm{~A}\end{array}$ & $\begin{array}{l}85.36 \\
\pm \\
2.04 \mathrm{~A}\end{array}$ & $\begin{array}{l}87.14 \\
\pm \\
2.05 \mathrm{~A}\end{array}$ \\
\hline
\end{tabular}

Control $88.91 \pm 1.40 \mathrm{~A}$

(b) Developmental period (days)

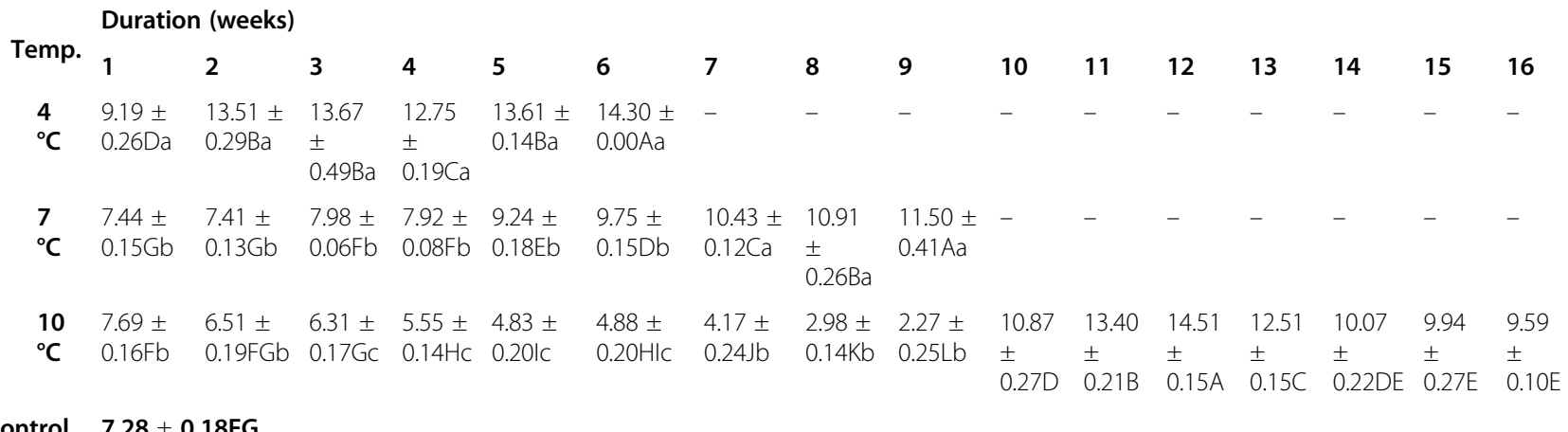

Control $\quad 7.28 \pm 0.18 \mathrm{FG}$ 
Table 2 Percentages of adults' emergences of Trichogrammatoidea bactrae in parental generation during storage of parasitoid larvae at different low temperatures

\begin{tabular}{|c|c|c|c|c|c|c|c|c|c|c|c|c|c|c|c|c|}
\hline \multicolumn{17}{|c|}{ Adults' emergence \% } \\
\hline \multirow{2}{*}{ Temp. } & \multicolumn{16}{|c|}{ Duration (weeks) } \\
\hline & 1 & 2 & 3 & 4 & 5 & 6 & 7 & 8 & 9 & 10 & 11 & 12 & 13 & 14 & 15 & 16 \\
\hline $\begin{array}{l}4 \\
{ }^{\circ} \mathrm{C}\end{array}$ & $\begin{array}{l}86.75 \\
\pm \\
1.4 \mathrm{BC}\end{array}$ & $\begin{array}{l}71.24 \\
\pm \\
0.95 C \mathrm{C}\end{array}$ & $\begin{array}{l}53.95 \\
\pm \\
6.68 \mathrm{EC}\end{array}$ & $\begin{array}{l}44.59 \pm \\
9.54 \mathrm{FC}\end{array}$ & $\begin{array}{l}61.00 \\
\pm \\
5.31 \mathrm{DC}\end{array}$ & $\begin{array}{l}37.67 \pm \\
2.91 \mathrm{Gc}\end{array}$ & - & - & - & - & - & - & - & - & - & - \\
\hline $\begin{array}{l}7 \\
{ }^{\circ} \mathrm{C}\end{array}$ & $\begin{array}{l}91.55 \\
\pm \\
1.15 \mathrm{Bb}\end{array}$ & $\begin{array}{l}86.52 \\
\pm \\
1.66 \mathrm{Cb}\end{array}$ & $\begin{array}{l}86.38 \\
\pm \\
1.98 \mathrm{Cb}\end{array}$ & $\begin{array}{l}78.26 \pm \\
1.46 \mathrm{Db}\end{array}$ & $\begin{array}{l}73.50 \\
\pm \\
2.05 \mathrm{~Eb}\end{array}$ & $\begin{array}{l}67.00 \pm \\
2.01 \mathrm{GHb}\end{array}$ & $\begin{array}{l}67.84 \pm \\
1.72 \mathrm{FGb}\end{array}$ & $\begin{array}{l}66.05 \\
\pm \\
1.18 \mathrm{Hb}\end{array}$ & $\begin{array}{l}49.30 \pm \\
2.16 l a\end{array}$ & - & - & - & - & - & - & - \\
\hline $\begin{array}{l}10 \\
{ }^{\circ} \mathrm{C}\end{array}$ & $\begin{array}{l}98.20 \\
\pm \\
0.50 \mathrm{Aa}\end{array}$ & $\begin{array}{l}98.81 \\
\pm \\
0.37 \mathrm{Aa}\end{array}$ & $\begin{array}{l}95.51 \\
\pm \\
1.09 \mathrm{Aa}\end{array}$ & $\begin{array}{l}91.91 \pm \\
1.12 \mathrm{Aba}\end{array}$ & $\begin{array}{l}89.67 \\
\pm \\
1.39 \mathrm{Ba}\end{array}$ & $\begin{array}{l}87.21 \pm \\
2.05 \mathrm{BCa}\end{array}$ & $\begin{array}{l}86.67 \pm \\
1.83 \mathrm{BCa}\end{array}$ & $\begin{array}{l}73.13 \\
\pm \\
2.44 \mathrm{Da}\end{array}$ & $\begin{array}{l}51.29 \pm \\
3.35 \mathrm{FGa}\end{array}$ & $\begin{array}{l}53.28 \\
\pm \\
3.37 \mathrm{EF}\end{array}$ & $\begin{array}{l}44.60 \\
\pm \\
2.78 \mathrm{H}\end{array}$ & $\begin{array}{l}47.07 \\
\pm \\
4.84 \mathrm{GH}\end{array}$ & $\begin{array}{l}33.18 \\
\pm \\
2.15 \mathrm{~J}\end{array}$ & $\begin{array}{l}24.21 \\
\pm \\
2.45 \mathrm{~K}\end{array}$ & $\begin{array}{l}34.36 \\
\pm \\
4.62 \mid J\end{array}$ & $\begin{array}{l}23.01 \\
\pm \\
2.33 \mathrm{~K}\end{array}$ \\
\hline
\end{tabular}

Control $\quad 97.40 \pm 0.85 \mathrm{AB}$

Means \pm SE sharing the same capital letters in the same row, and same small letters in the columns are statistically insignificant $(P \geq 0.05)$

\section{$F_{1}$ progeny}

Parasitism rate The percentage of parasitism in $\mathrm{F}_{1}$ progeny emerged from cold-exposed, did not change for 7 weeks, when the parasitoid was held at $7{ }^{\circ} \mathrm{C}(88.82 \%)$ and $10{ }^{\circ} \mathrm{C}(91.00 \%)$, the latter percentage was close to that in the control group (92.36\%) (Table 3 (a)). Although the adult emergence percentage in the parental generation after storage at $7{ }^{\circ} \mathrm{C}$ was low, the parasitism was higher in $\mathrm{F}_{1}$ than at the 2 other temperatures. However, temperature of $4{ }^{\circ} \mathrm{C}$ did not provide storage more than 2 weeks. The effect of temperature (A), storage period $(\mathrm{B})$, and the interactions $(\mathrm{A} \times \mathrm{B})$ was significantly

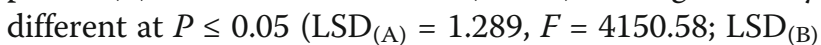

$=2.233, F=439.585 ;$ and $\operatorname{LSD}_{(\mathrm{A} \times \mathrm{B})}=3.868, F=$ 263.179).

Adults' emergence percentage The emergence rate of $\mathrm{F}_{1}$ progeny was not significantly changed in all the tested storage temperatures compared with the control (Table 3 (b)). High numbers of emergency were observed during all storage periods. At $7{ }^{\circ} \mathrm{C}$, the percentage of emerged adults was not different from the control up to 9 weeks of storage. Furthermore, when the parasitoid was held at $10{ }^{\circ} \mathrm{C}$, great rates of emergences were noticed and continued for 16 weeks. Regardless to storage periods, there was insignificant difference between 7 and $10{ }^{\circ} \mathrm{C}$ in the percentage of

Table 3 Percentages of parasitism and adult emergence rates of Trichogrammatoidea bactrae in $\mathrm{F}_{1}$ progeny during storage of parasitoid larvae at different low temperatures

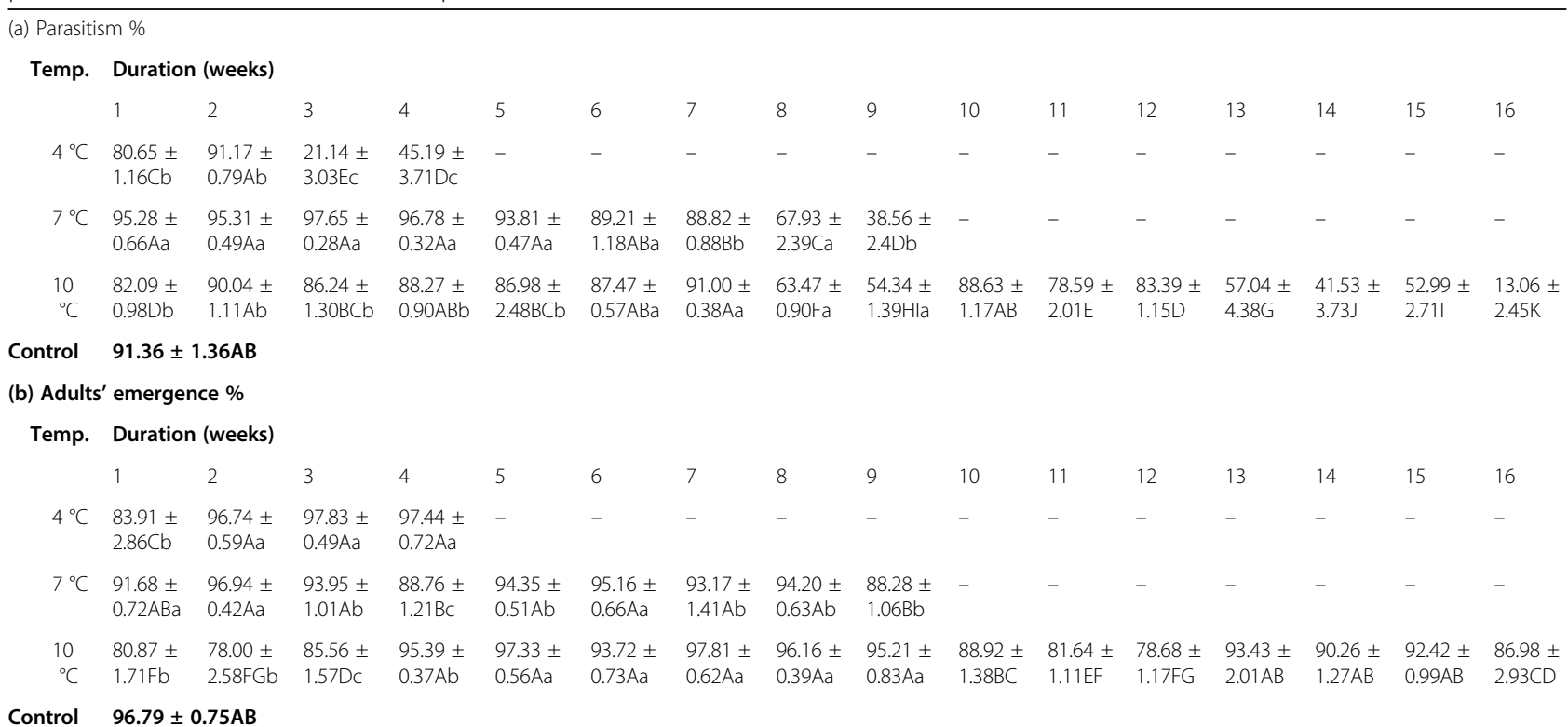


adult emergence. The effect of temperature (A), storage period $(\mathrm{B})$, and their interaction $(\mathrm{A} \times \mathrm{B})$ in adult emergence percentage was significantly different at $P$ $\leq 0.05\left(\mathrm{LSD}_{(\mathrm{A})}=9.734, F=16.95 ; \mathrm{LSD}_{(\mathrm{B})}=16.859, F\right.$ $=4.101$; and $\left.\operatorname{LSD}_{(\mathrm{A} \times \mathrm{B})}=29.201, F=9.503\right)$.

Percentages of female adults The majority of adults' emergence in the generation subjected to storage at low temperature was female-biased in all treatments but with different values (Table 4 (a)). The percentage of female adults emerged at $10{ }^{\circ} \mathrm{C}$ was significantly $(P=0.000)$ higher, followed by $7{ }^{\circ} \mathrm{C}$, while it was the lowest one at $4{ }^{\circ} \mathrm{C}$. In $\mathrm{F}_{1}$ progeny, the female percentage was similar somewhat with that of the parental generation (Table 4 (b)). There were significant $(P \leq 0.05)$ variations for the effect of temperature $(\mathrm{A})$, storage periods $(\mathrm{B})$, and storage period-temperature interaction $(\mathrm{A} \times \mathrm{B})$ in the parental generation $\left(\mathrm{LSD}_{(\mathrm{A})}=\right.$ $0.821, F=3021.527 ; \mathrm{LSD}_{(\mathrm{B})}=1.421, F=949.085$; and $\left.\operatorname{LSD}_{(\mathrm{A} \times \mathrm{B})}=2.462, F=347.235\right)$ and the $\mathrm{F}_{1}$ progeny $\left(\operatorname{LSD}_{(\mathrm{A})}\right.$ $=1.113, F=3087.604 ; \mathrm{LSD}_{(\mathrm{B})}=1.928, F=629.73$; and $\left.\operatorname{LSD}_{(\mathrm{A} \times \mathrm{B})}=3.339, F=272.043\right)$.

Longevity of adults The decrease in adults' longevity in the parental generation was more prominent than in $F_{1}$ progeny (Fig. 1). Fed adult parasitoids lived significantly $(P<0.001)$ longer than un-fed ones at all the tested temperatures in both generations. Moreover, insignificant effect $(P=0.143)$ was observed in the longevity of adults at 4 and $7{ }^{\circ} \mathrm{C}$ in the parental generation. At $10{ }^{\circ} \mathrm{C}$ storage temperature with different durations, adults' longevity was better for short- and long-term storages without detrimental effects to adults, regardless to whether supplied with food or starved in both generations. In the parental and the following generations $\left(\mathrm{F}_{1}\right)$, significant variations $(P \leq 0.05)$ for the effect of temperatures $(\mathrm{A})$, storage periods $(\mathrm{B})$, and their interactions $(\mathrm{A} \times \mathrm{B})$ were noticed on longevity of fed $\left(\mathrm{LSD}_{(\mathrm{A})}=0.694, F=36.589 ; \mathrm{LSD}_{(\mathrm{B})}=0.911, F\right.$ $=6.017 ; \mathrm{LSD}_{(\mathrm{A} \times \mathrm{B})}=2.081, F=6.732$ and $\mathrm{LSD}_{(\mathrm{A})}=1.468, F=$ 3087.604; $\mathrm{LSD}_{(\mathrm{B})}=1.928, F=629.73 ; \mathrm{LSD}_{(\mathrm{A} \times \mathrm{B})}=3.339, F=$ 272.043 , respectively) and of un-fed adults $\left(\mathrm{LSD}_{(\mathrm{A})}=0.289, F\right.$ $=74.089 ; \operatorname{LSD}_{(\mathrm{B})}=0.379, F=11.692 ; \operatorname{LSD}_{(\mathrm{A} \times \mathrm{B})}=0.657, F=$ 10.87 and $\operatorname{LSD}_{(\mathrm{A})}=0.24, F=171.416 ; \mathrm{LSD}_{(\mathrm{B})}=0.315, F=$ 9.108; $\operatorname{LSD}_{(\mathrm{A} \times \mathrm{B})}=0.546, F=16.107$, respectively).

\section{Storage of parasitoid pre-pupae (4 days after parasitism) Parental generation}

Parasitism percentage When the pre-pupae of T. bactrae were subjected to storage at the 3 temperatures (4, 7 , and $10{ }^{\circ} \mathrm{C}$ ), parasitism percentage was not affected with the control (Table 5 (a)). The 2-way ANOVA revealed that the effect of temperature $(\mathrm{A})$, storage period $(\mathrm{B})$, and storage period-temperature interaction $(\mathrm{A} \times \mathrm{B})$ had insignificant variations at $P \leq 0.05$.

Developmental period The length of cold exposure on the developmental period of the parasitoid, significantly $(P=0.000)$ increased in case of $4{ }^{\circ} \mathrm{C}$ than in the control and the 2 other temperatures (Table 5 (b)). It required the longest time at $4{ }^{\circ} \mathrm{C}$ to develop. The mean developmental period was 7.28 days, followed by 5.03 days at 7

Table 4 Percentages of Trichogrammatoidea bactrae females in parental and $F_{1}$ generations during storage of parasitoid larvae at different low temperatures

\begin{tabular}{|c|c|c|c|c|c|c|c|c|c|c|c|c|c|c|c|c|}
\hline \multicolumn{17}{|c|}{ (a) Parental generation } \\
\hline \multirow[t]{2}{*}{ Temp. } & \multicolumn{16}{|c|}{ Duration (weeks) } \\
\hline & 1 & 2 & 3 & 4 & 5 & 6 & 7 & 8 & 9 & 10 & 11 & 12 & 13 & 14 & 15 & 16 \\
\hline $4^{\circ} \mathrm{C}$ & $\begin{array}{l}81.00 \pm \\
0.33 \mathrm{Aa}\end{array}$ & $\begin{array}{l}67.5 \pm \\
0.78 C c\end{array}$ & $\begin{array}{l}62.00 \pm \\
0.46 D c\end{array}$ & $\begin{array}{l}73.37 \pm \\
0.65 \mathrm{Bb}\end{array}$ & $\begin{array}{l}54.5 \pm \\
0.57 E F C\end{array}$ & $\begin{array}{l}50.00 \pm \\
0.00 \mathrm{Fc}\end{array}$ & - & - & - & - & - & - & - & - & - & - \\
\hline $7^{\circ} \mathrm{C}$ & $\begin{array}{l}70.62 \pm \\
1.05 \mathrm{Cb}\end{array}$ & $\begin{array}{l}70.50 \pm \\
0.92 \mathrm{Cb}\end{array}$ & $\begin{array}{l}72.50 \pm \\
1.29 \mathrm{Cb}\end{array}$ & $\begin{array}{l}72.00 \pm \\
0.78 \mathrm{Cb}\end{array}$ & $\begin{array}{l}70.00 \pm \\
1.31 \mathrm{Cb}\end{array}$ & $\begin{array}{l}66.50 \pm \\
1.94 \mathrm{DEb}\end{array}$ & $\begin{array}{l}63.87 \pm \\
0.72 \mathrm{~Eb}\end{array}$ & $\begin{array}{l}69.50 \pm \\
1.18 \mathrm{CDa}\end{array}$ & $\begin{array}{l}77.87 \pm \\
0.29 \mathrm{Bb}\end{array}$ & - & - & - & - & - & - & - \\
\hline $\begin{array}{l}10 \\
{ }^{\circ} \mathrm{C}\end{array}$ & $\begin{array}{l}82.12 \pm \\
1.19 \mathrm{Aa}\end{array}$ & $\begin{array}{l}83.37 \pm \\
0.65 \mathrm{Aa}\end{array}$ & $\begin{array}{l}80.37 \pm \\
0.71 \mathrm{ABa}\end{array}$ & $\begin{array}{l}85.00 \pm \\
1.29 \mathrm{Aa}\end{array}$ & $\begin{array}{l}80.00 \pm \\
0.50 \mathrm{Aba}\end{array}$ & $\begin{array}{l}80.00 \pm \\
0.73 \mathrm{ABa}\end{array}$ & $\begin{array}{l}77.87 \pm \\
0.44 \mathrm{CDa}\end{array}$ & $\begin{array}{l}72.00 \pm \\
1.27 \mathrm{Ea}\end{array}$ & $\begin{array}{l}80.62 \pm \\
1.00 \mathrm{ABa}\end{array}$ & $\begin{array}{l}84.62 \\
\pm \\
0.68 \mathrm{~A}\end{array}$ & $\begin{array}{l}79.00 \pm \\
0.33 B C\end{array}$ & $\begin{array}{l}77.62 \pm \\
0.91 C D\end{array}$ & $\begin{array}{l}79.87 \pm \\
0.44 \mathrm{ABC}\end{array}$ & $\begin{array}{l}78.00 \\
\pm \\
0.00 \mathrm{C}\end{array}$ & $\begin{array}{l}79.50 \pm \\
0.42 A B C\end{array}$ & $\begin{array}{l}76.25 \pm \\
0.36 \mathrm{D}\end{array}$ \\
\hline
\end{tabular}

Control $\quad 84.62 \pm 0.62 \mathrm{~A}$

(b) $F_{1}$ generation

Temp. Duration (weeks)

$\begin{array}{llllllllll} & 1 & 2 & 3 & 4 & 5 & 6 & 7 & 8 & 9 \\ 4^{\circ} \mathrm{C} & 84.25 \pm & 63.12 \pm & 50.00 \pm & 53.37 \pm & - & - & - & - & - \\ & 0.56 \mathrm{Aa} & 3.45 \mathrm{BC} & 0.00 \mathrm{Dc} & 0.32 \mathrm{Cc} & & & & & \\ 7^{\circ} \mathrm{C} & 70.50 \pm & 70.62 \pm & 72.00 \pm & 68.50 \pm & 70.37 \pm & 69.00 \pm & 71.00 \pm & 69.50 \pm & 81.5 \pm \\ & 1.76 \mathrm{Bb} & 1.19 \mathrm{Bb} & 1.07 \mathrm{Bb} & 1.32 \mathrm{Cb} & 1.27 \mathrm{Ba} & 1.21 \mathrm{BCa} & 0.68 \mathrm{Bb} & 0.73 \mathrm{BCb} & 1.58 \mathrm{Aa} \\ 10 & 87.12 \pm & 84.00 \pm & 79.25 \pm & 74.75 \pm & 69.87 \pm & 70.25 \pm & 80.00 \pm & 77.52 \pm & 77.00 \pm \\ { }^{\circ} \mathrm{C} & 1.61 \mathrm{Aa} & 1.67 \mathrm{Aa} & 0.99 \mathrm{Ba} & 1.01 \mathrm{DEa} & 1.34 \mathrm{Fa} & 1.41 \mathrm{Fa} & 1.02 \mathrm{ABa} & 1.03 \mathrm{BCa} & 2.40 \mathrm{BCa}\end{array}$

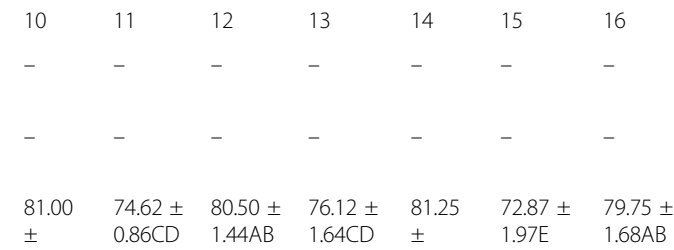

Control $\quad 85.00 \pm 0.73 \mathrm{~A}$

$\begin{array}{lllll} \pm & 0.86 C D & 1.44 \mathrm{AB} & 1.64 \mathrm{CD} & \pm \\ 1.57 \mathrm{~A} & & & & 0.45 \mathrm{~A}\end{array}$

Means \pm SE sharing the same capital letters in the same row, and same small letters in the columns are statistically insignificant $(P \geq 0.05)$ 


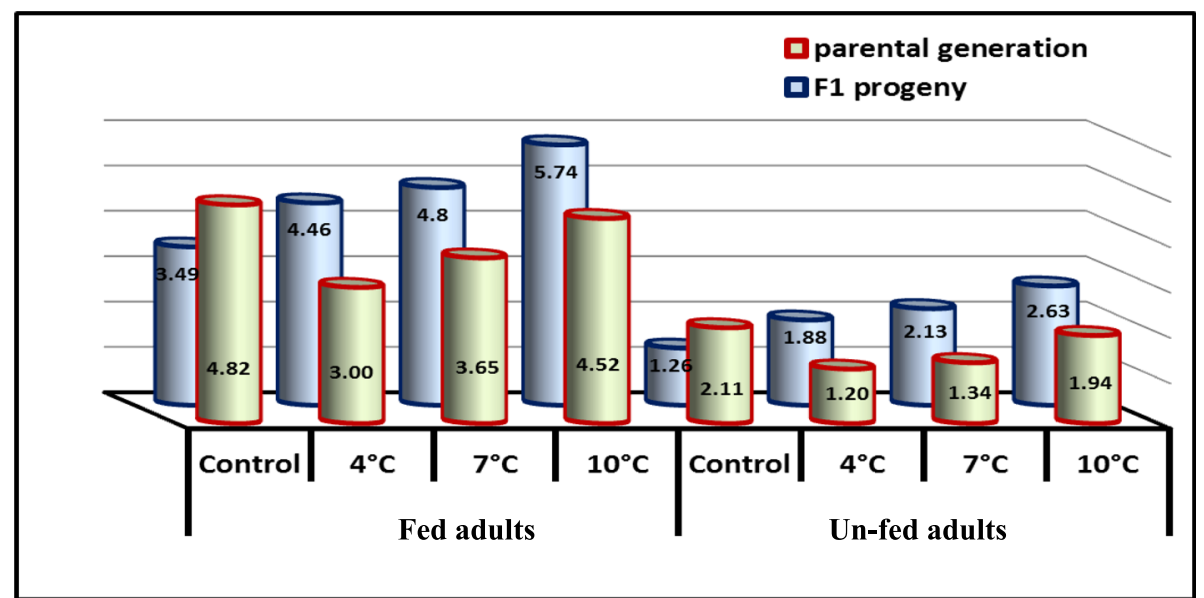

Fig. 1 Mean longevity of Trichogrammatoidea bactrae adults (fed and un-fed) of parental and $F_{1}$ progeny after storage of parasitoid larvae at different low temperatures

${ }^{\circ} \mathrm{C}$, and the faster one was 2.37 days at $10{ }^{\circ} \mathrm{C}$. Statistically, the developmental period after cold storage varied significantly $(P \leq 0.05)$ with temperatures $\left(\operatorname{LSD}_{(\mathrm{A})}=\right.$ $0.126, F=4589.366)$, storage durations $\left(\operatorname{LSD}_{(\mathrm{B})}=0.219\right.$, $F=49.867)$, and their interactions $\left(\operatorname{LSD}_{(\mathrm{A} \times \mathrm{B})}=0.288, F\right.$ $=300.014)$.

Adults' emergence percentage The ratio of parasitoid's emergence was significantly $(P=0.000)$ decreased as the period of cold exposure was prolonged according to different temperatures (Table 5 (c)). Compared to the control group (95.56\%), the emergence increased slightly (97.19\%) only after 1 week of storage at $4{ }^{\circ} \mathrm{C}$, then it declined sharply $(P=0.002)$. At $7{ }^{\circ} \mathrm{C}$, the ratio of emerged adults was significantly decreased $(P=0.000)$ till the $9^{\text {th }}$ week of storage $(14.15 \%)$. Furthermore, when the parasitoid was stored at $10{ }^{\circ} \mathrm{C}$, it emerged in high numbers and did not change significantly up to the $3^{\text {rd }}$ week. There were significant variations for the effect of temperature (A), storage period (B), and the interaction

Table 5 Percentages of parasitism, developmental period and adults' emergence of Trichogrammatoidea bactrae in parental generation during storage of parasitoid pre-pupae at different low temperatures

\begin{tabular}{|c|c|c|c|c|c|c|c|c|c|}
\hline \multirow{2}{*}{$\begin{array}{l}\text { Storage } \\
\text { period } \\
\text { (weeks) }\end{array}$} & \multicolumn{3}{|c|}{ (a) Parasitism \% } & \multicolumn{3}{|c|}{ (b) Developmental period } & \multicolumn{3}{|c|}{ (c) Adults' emergence \% } \\
\hline & $4^{\circ} \mathrm{C}$ & $7^{\circ} \mathrm{C}$ & $10^{\circ} \mathrm{C}$ & $4{ }^{\circ} \mathrm{C}$ & $7^{\circ} \mathrm{C}$ & $10^{\circ} \mathrm{C}$ & $4^{\circ} \mathrm{C}$ & $7^{\circ} \mathrm{C}$ & $10^{\circ} \mathrm{C}$ \\
\hline Control & \multicolumn{3}{|l|}{$88.64 \pm 0.88 A$} & \multicolumn{3}{|l|}{$4.93 \pm 0.15$} & \multicolumn{3}{|l|}{$95.56 \pm 0.47 A$} \\
\hline 1 & $90.30 \pm 0.70 \mathrm{Aa}$ & $\begin{array}{l}88.48 \pm \\
0.83 \mathrm{Aa}\end{array}$ & $\begin{array}{l}89.30 \pm \\
1.88 \mathrm{Aa}\end{array}$ & $6.43 \pm 0.15 \mathrm{Da}$ & $\begin{array}{l}5.47 \pm \\
0.20 \mathrm{Bb}\end{array}$ & $\begin{array}{l}5.13 \pm \\
0.28 \mathrm{Ab}\end{array}$ & $\begin{array}{l}97.19 \pm \\
0.61 \mathrm{Aa}\end{array}$ & $\begin{array}{l}65.49 \pm \\
2.49 \mathrm{Ab}\end{array}$ & $98.85 \pm 0.63 \mathrm{Aa}$ \\
\hline 2 & $91.20 \pm 0.67 \mathrm{Aa}$ & $\begin{array}{l}90.26 \pm \\
1.25 \mathrm{Aa}\end{array}$ & $\begin{array}{l}90.04 \pm \\
1.21 \mathrm{Aa}\end{array}$ & $5.37 \pm 0.16 \mathrm{Fa}$ & $\begin{array}{l}4.63 \pm \\
0.19 B b\end{array}$ & $\begin{array}{l}4.56 \pm \\
0.19 \mathrm{Ab}\end{array}$ & $\begin{array}{l}88.93 \pm \\
1.47 \mathrm{Bb}\end{array}$ & $\begin{array}{l}56.92 \pm \\
2.71 \mathrm{BC}\end{array}$ & $96.00 \pm 0.65 \mathrm{Aa}$ \\
\hline 3 & $\begin{array}{l}89.60 \pm \\
1.53 \mathrm{Aa}\end{array}$ & $\begin{array}{l}89.06 \pm \\
0.36 \mathrm{Aa}\end{array}$ & $\begin{array}{l}92.76 \pm \\
1.40 \mathrm{Aa}\end{array}$ & $5.86 \pm 0.14 \mathrm{Ea}$ & $\begin{array}{l}4.40 \pm \\
0.22 \mathrm{Bb}\end{array}$ & $\begin{array}{l}2.69 \pm \\
0.15 C c\end{array}$ & $\begin{array}{l}89.12 \pm \\
1.12 \mathrm{Bb}\end{array}$ & $\begin{array}{l}55.84 \pm \\
1.08 \mathrm{BC}\end{array}$ & $94.42 \pm 0.88 \mathrm{Aa}$ \\
\hline 4 & $\begin{array}{l}91.58 \pm \\
1.03 \mathrm{Aa}\end{array}$ & $\begin{array}{l}89.47 \pm \\
0.88 \mathrm{Aa}\end{array}$ & $\begin{array}{l}91.00 \pm \\
1.17 \mathrm{Aa}\end{array}$ & $7.73 \pm 0.42 \mathrm{Ca}$ & $\begin{array}{l}4.59 \pm \\
0.05 \mathrm{Bb}\end{array}$ & $\begin{array}{l}3.18 \pm \\
0.25 B C\end{array}$ & $\begin{array}{l}47.64 \pm \\
2.94 C c\end{array}$ & $\begin{array}{l}49.21 \pm \\
1.97 C b\end{array}$ & $87.13 \pm 1.21 \mathrm{Ba}$ \\
\hline 5 & $\begin{array}{l}88.55 \pm \\
1.68 \mathrm{Aa}\end{array}$ & $\begin{array}{l}88.78 \pm \\
1.29 \mathrm{Aa}\end{array}$ & $\begin{array}{l}89.20 \pm \\
1.25 \mathrm{Aa}\end{array}$ & $9.77 \pm 0.11 \mathrm{Aa}$ & $\begin{array}{l}4.35 \pm \\
0.11 \mathrm{Bb}\end{array}$ & $\begin{array}{l}2.84 \pm \\
0.12 \mathrm{Cc}\end{array}$ & $\begin{array}{l}22.65 \pm \\
2.13 \mathrm{Dc}\end{array}$ & $\begin{array}{l}49.44 \pm \\
3.79 \mathrm{Cb}\end{array}$ & $81.95 \pm 2.28 \mathrm{Ca}$ \\
\hline 6 & $\begin{array}{l}87.72 \pm \\
2.73 \mathrm{Aa}\end{array}$ & $\begin{array}{l}86.13 \pm \\
1.15 \mathrm{Aa}\end{array}$ & $\begin{array}{l}89.15 \pm \\
1.19 \mathrm{Aa}\end{array}$ & $8.64 \pm 0.11 \mathrm{Ba}$ & $\begin{array}{l}5.12 \pm \\
0.13 \mathrm{Bb}\end{array}$ & $\begin{array}{l}1.36 \pm \\
0.17 \mathrm{Dc}\end{array}$ & $\begin{array}{l}14.33 \pm \\
1.84 \mathrm{Ec}\end{array}$ & $\begin{array}{l}35.47 \pm \\
3.63 \mathrm{Db}\end{array}$ & $\begin{array}{l}68.18 \pm \\
5.19 \mathrm{Da}\end{array}$ \\
\hline 7 & $\begin{array}{l}85.38 \pm \\
1.11 \mathrm{Ab}\end{array}$ & $\begin{array}{l}84.46 \pm \\
1.79 \mathrm{Ab}\end{array}$ & $\begin{array}{l}92.12 \pm \\
0.87 \mathrm{Aa}\end{array}$ & $\begin{array}{l}9.21 \pm \\
0.01 \mathrm{ABa}\end{array}$ & $\begin{array}{l}4.86 \pm \\
0.03 \mathrm{Bb}\end{array}$ & $\begin{array}{l}0.75 \pm \\
0.10 \mathrm{Ec}\end{array}$ & $9.73 \pm 2.60 \mathrm{Fc}$ & $\begin{array}{l}33.50 \pm \\
1.65 \mathrm{Db}\end{array}$ & $\begin{array}{l}56.12 \pm \\
2.74 \mathrm{EFa}\end{array}$ \\
\hline 8 & $\begin{array}{l}87.37 \pm \\
1.77 \mathrm{Ab}\end{array}$ & $\begin{array}{l}85.62 \pm \\
0.84 \mathrm{Ab}\end{array}$ & $\begin{array}{l}91.59 \pm \\
0.54 \mathrm{Aa}\end{array}$ & $9.89 \pm 0.06 \mathrm{Aa}$ & $\begin{array}{l}5.26 \pm \\
0.13 \mathrm{Bb}\end{array}$ & $\begin{array}{l}0.68 \pm \\
0.11 E c\end{array}$ & $9.76 \pm 1.77 \mathrm{FC}$ & $\begin{array}{l}26.89 \pm \\
1.48 \mathrm{~Eb}\end{array}$ & $48.37 \pm 4.19 \mathrm{Fa}$ \\
\hline 9 & $\begin{array}{l}83.58 \pm \\
3.91 \mathrm{Ba}\end{array}$ & $\begin{array}{l}85.79 \pm \\
2.86 \mathrm{Aa}\end{array}$ & $\begin{array}{l}70.04 \pm \\
2.05 \mathrm{Bb}\end{array}$ & $5.16 \pm 0.00 \mathrm{Fb}$ & $\begin{array}{l}6.56 \pm \\
0.13 \mathrm{Aa}\end{array}$ & $\begin{array}{l}0.17 \pm \\
0.00 \mathrm{Fc}\end{array}$ & $1.76 \pm 0.56 \mathrm{Gc}$ & $\begin{array}{l}14.15 \pm \\
1.75 \mathrm{Fa}\end{array}$ & $5.93 \pm 2.14 \mathrm{~Gb}$ \\
\hline
\end{tabular}

Means \pm SE sharing the same capital letters in the same columns, and same small letters in the rows are statistically insignificant $(P \geq 0.05)$ 
$(\mathrm{A} \times \mathrm{B})$ on the adults' emergence percentage at $P \leq 0.05$ $\left(\operatorname{LSD}_{(\mathrm{A})}=8.463, F=37.25 ; \mathrm{LSD}_{(\mathrm{B})}=14.659, F=9.004\right.$; and $\left.\operatorname{LSD}_{(\mathrm{A} \times \mathrm{B})}=25.39, F=4.845\right)$.

\section{$F_{1}$ progeny}

Parasitism rate Prolonged storage of the parental generation declined parasitism performance in progeny in all the storage temperatures (Table 6 (a)). The parasitism percentage emerged from $4{ }^{\circ} \mathrm{C}$ during the first 2 weeks was similar to control $(92.02 \%)$; then, it decreased significantly $(P=0.000)$. The parasitoid adults failed to parasitize any eggs in the progeny from the $7^{\text {th }}$ week of storage. Although the adult emergence percentage in the parental generation after storage at $7{ }^{\circ} \mathrm{C}$ was low, the parasitism rate was high in $\mathrm{F}_{1}$ and increased significantly $(P<0.001)$ than the control and the other temperatures up to 5 weeks. Moreover, in case of $10{ }^{\circ} \mathrm{C}$, the parasitism in $\mathrm{F}_{1}$ was influenced by cold exposure and the percentage decreased slightly. After 9 weeks of storage in the parental generation, the females failed to parasitize any eggs. The effect of temperature (A), storage period (B), and the interaction $(\mathrm{A} \times \mathrm{B})$ in $\mathrm{F}_{1}$ progeny was significantly $(P \leq 0.05)$ varied $\left(\operatorname{LSD}_{(\mathrm{A})}=1.221, F=1285.299\right.$; $\mathrm{LSD}_{(\mathrm{B})}=2.116, F=782.419$; and $\mathrm{LSD}_{(\mathrm{A} \times \mathrm{B})}=3.664, F=$ 221.383).

Adults' emergence percentage The effect of cold storage in the parental generation on the adults' emergence of progeny had not changed significantly at 7 and $10{ }^{\circ} \mathrm{C}$. High emergency rates were observed $(\geq 86 \%$ ) during all storage periods throughout different temperatures (Table 6 (b)). Statistically, the different temperatures (A), storage duration $(\mathrm{B})$, and their interaction $(\mathrm{A} \times \mathrm{B})$ had significant effects on the adult emergence percentage in $F_{1}$ progeny at $P \leq 0.05$
$\left(\mathrm{LSD}_{(\mathrm{A})}=10.136, F=10.02 ; \mathrm{LSD}_{(\mathrm{B})}=17.556, F=4.091\right.$; and $\left.\operatorname{LSD}_{(\mathrm{A} \times \mathrm{B})}=30.408, F=3.319\right)$.

Percentages of female adults The majority of adult emergency in the generation subjected to storage at low temperature was strongly female-biased in all treatments with different values (Table 7 (a)). The females percentage emerged from storage at 4 and $10{ }^{\circ} \mathrm{C}$ were not significantly $(P=0.613)$ affected by the length of storage duration, but $7{ }^{\circ} \mathrm{C}$ was the lowest one. Although the ratio of females emerged from $7{ }^{\circ} \mathrm{C}$ was significantly different $(P=0.000)$ than the control but had not change in relation to storage period for 9 weeks. In the following generation $\left(F_{1}\right)$, the overall sex ratio of emerged adults was female biased, but it was significantly different $(P=$ $0.000)$ from control in all tested temperatures and storage durations (Table 7 (b)). The percentage of female in progeny increased but not significantly $(P \geq 0.2)$ differed than the parental generation. There were significant variations $(P \leq 0.05)$ of temperature $(\mathrm{A})$, storage period $(\mathrm{B})$, and storage period-temperature interaction $(\mathrm{A} \times \mathrm{B})$ on females percentage in the parental generation $\left(\mathrm{LSD}_{(\mathrm{A})}=\right.$ $1.320, F=380.428 ; \operatorname{LSD}_{(\mathrm{B})}=2.286, F=39.152$; and $\left.\operatorname{LSD}_{(\mathrm{A} \times \mathrm{B})}=3.959, F=12.347\right)$ and also in the progeny $\left(\operatorname{LSD}_{(\mathrm{A})}=0.993, F=614.293 ; \mathrm{LSD}_{(\mathrm{B})}=1.721, F=\right.$ 561.701 ; and $\left.\operatorname{LSD}_{(\mathrm{A} \times \mathrm{B})}=2.98, F=428.99\right)$.

Longevity of adults Fed adult parasitoids significantly $(P=0.000)$ lived much longer than the starved ones at all tested temperatures and storage durations in both generations (parental and $F_{1}$ progeny) (Fig. 2). For the longevity of parasitoid stored at $10{ }^{\circ} \mathrm{C}$, adults lived nonsignificantly $(P>0.5)$ longer than that maintained at 4 and $7{ }^{\circ} \mathrm{C}$, regardless to whether supplied with food or starved. The length of cold exposure at the 3 low temperatures occurred in the parental generation did not

Table 6 Percentages of parasitism and adults' emergence of Trichogrammatoidea bactrae in $\mathrm{F}_{1}$ progeny during storage of parasitoid pre-pupae at different low temperatures

\begin{tabular}{|c|c|c|c|c|c|c|}
\hline \multirow{2}{*}{$\begin{array}{l}\text { Storage } \\
\text { period } \\
\text { (weeks) }\end{array}$} & \multicolumn{3}{|l|}{ (a) Parasitism \% } & \multicolumn{3}{|c|}{ (b) Adults' emergence \% } \\
\hline & $4^{\circ} \mathrm{C}$ & $7^{\circ} \mathrm{C}$ & $10^{\circ} \mathrm{C}$ & $4^{\circ} \mathrm{C}$ & $7{ }^{\circ} \mathrm{C}$ & $10^{\circ} \mathrm{C}$ \\
\hline Control & $92.02 \pm 0.92 \mathrm{~A}$ & & & $95.63 \pm 1.24 \mathrm{~A}$ & & \\
\hline 1 & $91.05 \pm 0.43 \mathrm{AC}$ & $96.58 \pm 0.52 \mathrm{Aa}$ & $93.18 \pm 0.40 \mathrm{Ab}$ & $87.28 \pm 0.78 \mathrm{BC}$ & $98.32 \pm 0.70 A a$ & $95.49 \pm 0.30 \mathrm{Ab}$ \\
\hline 2 & $92.26 \pm 0.36 \mathrm{Ab}$ & $96.58 \pm 0.56 \mathrm{Aa}$ & $88.68 \pm 1.26 \mathrm{BCC}$ & $88.84 \pm 2.52 \mathrm{Bab}$ & $94.20 \pm 0.85 \mathrm{Aa}$ & $84.71 \pm 2.56 \mathrm{Bb}$ \\
\hline 3 & $82.13 \pm 1.19 \mathrm{BC}$ & $95.73 \pm 0.61 \mathrm{Aa}$ & $91.21 \pm 0.98 \mathrm{Ab}$ & $96.10 \pm 1.13 \mathrm{Aab}$ & $97.36 \pm 1.06 \mathrm{Aa}$ & $93.82 \pm 0.91 \mathrm{Ab}$ \\
\hline 4 & $80.13 \pm 0.62 \mathrm{BCC}$ & $95.57 \pm 0.49 \mathrm{Aa}$ & $87.38 \pm 1.05 \mathrm{Cb}$ & $91.67 \pm 0.51 \mathrm{Bbc}$ & $97.32 \pm 0.32 \mathrm{Aa}$ & $93.88 \pm 1.30 \mathrm{Ab}$ \\
\hline 5 & $78.53 \pm 0.52 \mathrm{Cb}$ & $96.94 \pm 0.25 \mathrm{Aa}$ & $90.61 \pm 0.51 \mathrm{ABa}$ & $94.52 \pm 0.45 \mathrm{Aa}$ & $93.71 \pm 0.80 \mathrm{Aa}$ & $96.19 \pm 0.64 \mathrm{Aa}$ \\
\hline 6 & $16.44 \pm 4.09 D c$ & $81.21 \pm 0.94 \mathrm{Bb}$ & $72.19 \pm 1.15 \mathrm{Ec}$ & $81.74 \pm 4.55 \mathrm{Cb}$ & $87.30 \pm 1.37 \mathrm{Bb}$ & $87.69 \pm 1.03 \mathrm{Bb}$ \\
\hline 7 & - & $82.85 \pm 1.08 \mathrm{Ba}$ & $76.03 \pm 1.74 \mathrm{Db}$ & - & $93.37 \pm 0.63 \mathrm{Ab}$ & $96.38 \pm 0.70 \mathrm{Aa}$ \\
\hline 8 & - & $70.09 \pm 2.03 \mathrm{Ca}$ & $34.67 \pm 3.13 \mathrm{Fb}$ & - & $86.60 \pm 1.46 \mathrm{Bb}$ & $93.24 \pm 1.01 \mathrm{Aa}$ \\
\hline 9 & - & $60.23 \pm 1.15 \mathrm{Da}$ & - & - & $92.65 \pm 0.80 \mathrm{~A}$ & - \\
\hline
\end{tabular}

Means \pm SE sharing the same capital letters in the same columns, and the same small letters in the rows are statistically insignificant $(P \geq 0.05)$ 
Table 7 Percentages of Trichogrammatoidea bactrae females in parental and $F_{1}$ generations during storage of parasitoid pre-pupae at different low temperatures

\begin{tabular}{|c|c|c|c|c|c|c|}
\hline \multirow{3}{*}{$\begin{array}{l}\text { Storage } \\
\text { period } \\
\text { (weeks) }\end{array}$} & \multicolumn{6}{|l|}{ Females (\%) } \\
\hline & \multicolumn{3}{|c|}{ (a) Parental generation } & \multicolumn{3}{|l|}{ (b) $F_{\mathbf{1}}$ progeny } \\
\hline & $4{ }^{\circ} \mathrm{C}$ & $7^{\circ} \mathrm{C}$ & $10^{\circ} \mathrm{C}$ & $4^{\circ} \mathrm{C}$ & $7^{\circ} \mathrm{C}$ & $10{ }^{\circ} \mathrm{C}$ \\
\hline Control & $82.78 \pm 1.52 \mathrm{~A}$ & & & $91.12 \pm 1.65 A$ & & \\
\hline 1 & $81.55 \pm 1.07 \mathrm{Aa}$ & $68.87 \pm 3.57 \mathrm{CDb}$ & $82.33 \pm 1.93 \mathrm{Aa}$ & $90.00 \pm 0.71 \mathrm{Aa}$ & $77.00 \pm 1.49 \mathrm{Bb}$ & $91.00 \pm 1.49 \mathrm{ABa}$ \\
\hline 2 & $82.55 \pm 0.82 \mathrm{Aa}$ & $67.37 \pm 1.63 \mathrm{Db}$ & $83.22 \pm 2.01 \mathrm{Aa}$ & $89.25 \pm 0.49 \mathrm{ABb}$ & $70.12 \pm 1.57 \mathrm{Cc}$ & $91.12 \pm 0.48 \mathrm{Aa}$ \\
\hline 3 & $82.44 \pm 1.60 \mathrm{Aa}$ & $70.87 \pm 0.35 \mathrm{Cb}$ & $81.89 \pm 1.52 \mathrm{Aa}$ & $88.00 \pm 0.57 \mathrm{Ba}$ & $71.00 \pm 0.96 \mathrm{Cb}$ & $88.00 \pm 0.33 \mathrm{BCa}$ \\
\hline 4 & $83.89 \pm 0.48 \mathrm{Aa}$ & $71.37 \pm 1.40 \mathrm{BCC}$ & $81.00 \pm 0.63 \mathrm{Ab}$ & $84.12 \pm 1.01 \mathrm{Ca}$ & $70.75 \pm 0.96 \mathrm{Cb}$ & $87.25 \pm 0.41 \mathrm{Ca}$ \\
\hline 5 & $78.89 \pm 0.12 \mathrm{Aa}$ & $70.50 \pm 2.34 \mathrm{Cb}$ & $78.33 \pm 0.78 \mathrm{BCa}$ & $81.00 \pm 1.66 \mathrm{Da}$ & $70.00 \pm 0.82 \mathrm{Cb}$ & $87.12 \pm 0.29 \mathrm{Ca}$ \\
\hline 6 & $81.11 \pm 0.27 \mathrm{Ab}$ & $74.00 \pm 1.00 \mathrm{BC}$ & $85.00 \pm 1.31 \mathrm{Aa}$ & $73.00 \pm 0.42 \mathrm{~Eb}$ & $70.87 \pm 0.69 C c$ & $82.25 \pm 0.36 \mathrm{Da}$ \\
\hline 7 & $81.00 \pm 0.77 \mathrm{Aa}$ & $71.37 \pm 1.15 B C b$ & $79.11 \pm 0.74 \mathrm{ABa}$ & - & $70.25 \pm 1.01 \mathrm{Cb}$ & $65.50 \pm 1.43 \mathrm{Fc}$ \\
\hline 8 & $66.33 \pm 0.26 \mathrm{BC}$ & $69.25 \pm 1.50 \mathrm{Cb}$ & $76.00 \pm 1.07 \mathrm{Ca}$ & - & $70.50 \pm 1.02 \mathrm{Cb}$ & $71.12 \pm 1.87 \mathrm{~Eb}$ \\
\hline 9 & $50.00 \pm 0.00 C c$ & $63.87 \pm 0.54 \mathrm{Ea}$ & $51.75 \pm 0.41 \mathrm{Db}$ & - & $63.25 \pm 0.56 \mathrm{D}$ & - \\
\hline
\end{tabular}

Means \pm SE sharing the same capital letters in the same columns, and same small letters in the rows are statistically insignificant $(P \geq 0.05)$

influence negatively surviving of adults in the progeny comparable to control. At $4{ }^{\circ} \mathrm{C}$, longevity of adult parasitoids in $\mathrm{F}_{1}$ progeny had non-significantly changed $(P=$ $0.706,0.685)$ than the parental generation, but it prolonged significantly at $7{ }^{\circ} \mathrm{C}(P=0.001,0.004)$ in both fed and un-fed adults, respectively. On the other hand, the longevity of parasitoid in progeny after parental storage at $10{ }^{\circ} \mathrm{C}$, the adult survived longer but non-significantly $(P=0.485,0.082)$ than the control and parental generation in case of fed but significantly increased $(P=$ $0.003,0.040)$ for un-fed adults, respectively. Statistically, all the main effects and their interactions proved to be significant $(P<0.05)$ on longevity of adults in the parental and the progeny in case of fed $\left(\operatorname{LSD}_{(\mathrm{A})}=0.413, F=\right.$ 4.178; $\operatorname{LSD}_{(\mathrm{B})}=0.716, F=8.462 ; \operatorname{LSD}_{(\mathrm{A} \times \mathrm{B})}=1.24, F=$ 7.256 and $\operatorname{LSD}_{(\mathrm{A})}=0.993, F=614.293 ; \mathrm{LSD}_{(\mathrm{B})}=1.721, F$ $=561.701 ; \operatorname{LSD}_{(\mathrm{A} \times \mathrm{B})}=2.98, F=428.99$, respectively $)$ and starved adults $\left(\operatorname{LSD}_{(\mathrm{A})}=0.188, F=19.828 ; \mathrm{LSD}_{(\mathrm{B})}=\right.$ $0.325, F=15.349 ; \operatorname{LSD}_{(\mathrm{A} \times \mathrm{B})}=0.563, F=7.56$ and $\mathrm{LSD}_{(\mathrm{A})}=0.232, F=26.533 ; \mathrm{LSD}_{(\mathrm{B})}=0.402, F=9.296$; $\mathrm{LSD}_{(\mathrm{A} \times \mathrm{B})}=0.696, F=14.058$, respectively).

\section{Storage of parasitoid pupae (6 days after parasitism) Parental generation}

Parasitism percentage When the pupae of $T$. bactrae were maintained at the 3 storage temperatures, the mean percentage of parasitism was not influenced negatively than the control during all storage periods (Table 8 (a)). The effect of temperature (A), storage period (B), and storage period-temperature interaction $(\mathrm{A} \times \mathrm{B})$ had insignificant $(P \leq 0.05)$ variations in parasitism percentage.

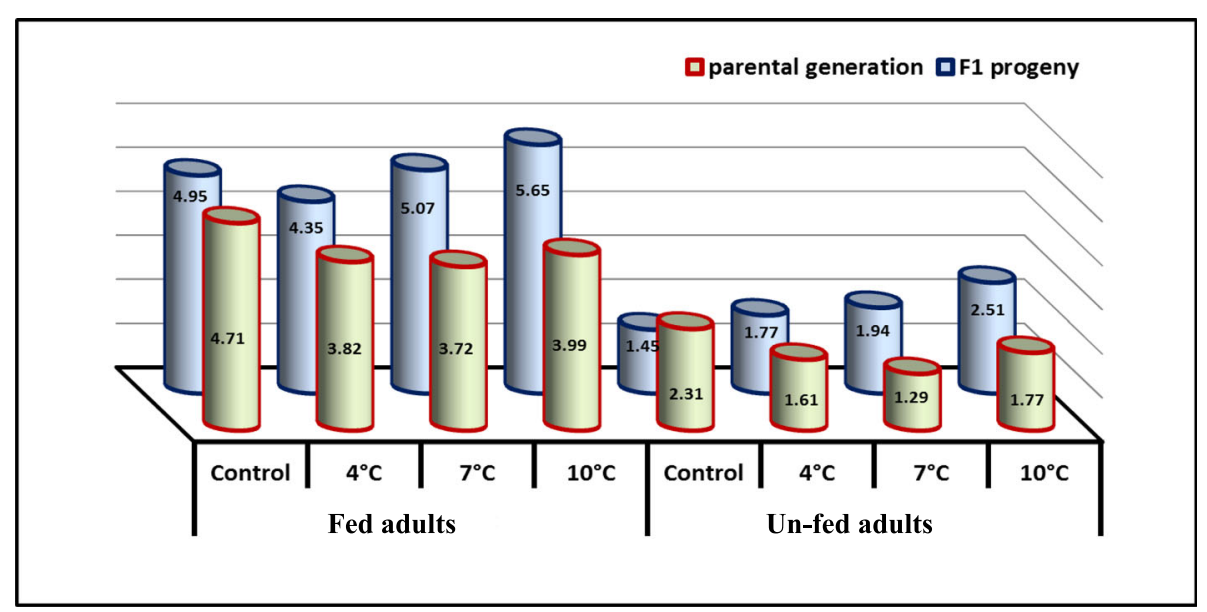

Fig. 2 Mean longevity of Trichogrammatoidea bactrae adults (fed and un-fed) of parental and $F_{1}$ progeny during storage of parasitoid pre-pupae at different low temperatures 
Table 8 Effect of cold storage on the parasitism\%, developmental period and adults' emergence \% of Trichogrammatoidea bactrae in parental generation during storage of parasitoid pupae at different low temperatures

\begin{tabular}{|c|c|c|c|c|c|c|c|c|c|}
\hline \multirow{2}{*}{$\begin{array}{l}\text { Storage } \\
\text { period } \\
\text { (weeks) }\end{array}$} & \multicolumn{3}{|c|}{ (a) Parasitism \% } & \multicolumn{3}{|c|}{ (b) Developmental period } & \multicolumn{3}{|c|}{ (c) Adults' emergence \% } \\
\hline & $4^{\circ} \mathrm{C}$ & $7^{\circ} \mathrm{C}$ & $10^{\circ} \mathrm{C}$ & $4^{\circ} \mathrm{C}$ & $7^{\circ} \mathrm{C}$ & $10^{\circ} \mathrm{C}$ & $4{ }^{\circ} \mathrm{C}$ & $7^{\circ} \mathrm{C}$ & $10^{\circ} \mathrm{C}$ \\
\hline Control & \multicolumn{3}{|c|}{$92.67 \pm 0.94 \mathrm{~A}$} & \multicolumn{3}{|l|}{$3.79 \pm 0.17$} & \multicolumn{3}{|c|}{$97.07 \pm 0.55 \mathrm{AB}$} \\
\hline 1 & $\begin{array}{l}92.68 \pm \\
1.39 A a b\end{array}$ & $\begin{array}{l}92.24 \pm \\
0.70 \mathrm{Ab}\end{array}$ & $\begin{array}{l}94.49 \pm \\
0.44 \mathrm{Aa}\end{array}$ & $\begin{array}{l}3.78 \pm \\
0.25 \mathrm{Da}\end{array}$ & $\begin{array}{l}3.18 \pm \\
0.28 \mathrm{Da}\end{array}$ & $\begin{array}{l}3.63 \pm \\
0.20 \mathrm{Aa}\end{array}$ & $\begin{array}{l}98.17 \pm \\
0.21 \mathrm{Aa}\end{array}$ & $\begin{array}{l}91.56 \pm \\
1.62 \mathrm{Cb}\end{array}$ & $\begin{array}{l}97.67 \pm \\
0.73 \mathrm{Aa}\end{array}$ \\
\hline 2 & $\begin{array}{l}93.36 \pm \\
0.75 \mathrm{Aa}\end{array}$ & $\begin{array}{l}91.50 \pm \\
0.81 \mathrm{Aa}\end{array}$ & $\begin{array}{l}89.62 \pm \\
1.46 \mathrm{Aa}\end{array}$ & $3.06 \pm 0.06 \mathrm{Ea}$ & $\begin{array}{l}3.00 \pm \\
0.12 \mathrm{Dab}\end{array}$ & $\begin{array}{l}2.66 \pm \\
0.15 \mathrm{Bb}\end{array}$ & $\begin{array}{l}95.18 \pm \\
1.03 \mathrm{Ba}\end{array}$ & $\begin{array}{l}76.30 \pm \\
2.76 \mathrm{Db}\end{array}$ & $\begin{array}{l}97.18 \pm \\
0.37 \mathrm{Aa}\end{array}$ \\
\hline 3 & $\begin{array}{l}93.45 \pm \\
0.43 \mathrm{Aa}\end{array}$ & $\begin{array}{l}90.87 \pm \\
0.90 \mathrm{Ab}\end{array}$ & $\begin{array}{l}92.00 \pm \\
1.11 \mathrm{Aab}\end{array}$ & $\begin{array}{l}3.69 \pm \\
0.17 \mathrm{Da}\end{array}$ & $\begin{array}{l}3.13 \pm \\
0.15 \mathrm{Db}\end{array}$ & $1.23 \pm 0.09 C \mathrm{C}$ & $\begin{array}{l}79.84 \pm \\
2.41 \mathrm{Cb}\end{array}$ & $\begin{array}{l}60.59 \pm \\
1.64 \mathrm{EC}\end{array}$ & $94.24 \pm 0.66 \mathrm{Ba}$ \\
\hline 4 & $\begin{array}{l}93.55 \pm \\
0.41 \mathrm{Aa}\end{array}$ & $\begin{array}{l}90.52 \pm \\
0.61 \mathrm{Ab}\end{array}$ & $\begin{array}{l}88.94 \pm \\
1.03 \mathrm{Ab}\end{array}$ & $\begin{array}{l}5.47 \pm \\
0.19 \mathrm{Ca}\end{array}$ & $\begin{array}{l}3.01 \pm \\
0.12 \mathrm{Db}\end{array}$ & $\begin{array}{l}1.18 \pm \\
0.03 C D C\end{array}$ & $\begin{array}{l}66.65 \pm \\
2.01 \mathrm{Db}\end{array}$ & $\begin{array}{l}46.21 \pm \\
2.80 \mathrm{Fc}\end{array}$ & $\begin{array}{l}92.86 \pm \\
0.40 \mathrm{Ca}\end{array}$ \\
\hline 5 & $\begin{array}{l}92.29 \pm \\
0.89 \mathrm{Aa}\end{array}$ & $\begin{array}{l}87.43 \pm \\
2.17 \mathrm{Aba}\end{array}$ & $\begin{array}{l}90.07 \pm \\
1.91 \mathrm{Aa}\end{array}$ & $\begin{array}{l}6.57 \pm \\
0.18 \mathrm{Aa}\end{array}$ & $\begin{array}{l}3.50 \pm \\
0.10 C b\end{array}$ & $\begin{array}{l}1.10 \pm \\
0.22 \mathrm{DC}\end{array}$ & $\begin{array}{l}38.99 \pm \\
3.05 \mathrm{~Eb}\end{array}$ & $\begin{array}{l}41.01 \pm \\
2.78 \mathrm{~Gb}\end{array}$ & $\begin{array}{l}88.87 \pm \\
1.24 \mathrm{Da}\end{array}$ \\
\hline 6 & $\begin{array}{l}90.76 \pm \\
\text { 1.64Aab }\end{array}$ & $\begin{array}{l}86.95 \pm \\
1.42 \mathrm{Bb}\end{array}$ & $\begin{array}{l}90.96 \pm \\
0.77 \mathrm{Aa}\end{array}$ & $\begin{array}{l}5.78 \pm \\
0.16 \mathrm{BCa}\end{array}$ & $\begin{array}{l}3.74 \pm \\
0.21 \mathrm{Cb}\end{array}$ & $0.87 \pm 0.19 \mathrm{EC}$ & $\begin{array}{l}22.49 \pm \\
2.30 \mathrm{FC}\end{array}$ & $\begin{array}{l}32.14 \pm \\
2.52 \mathrm{Hb}\end{array}$ & $\begin{array}{l}90.41 \pm \\
1.61 \mathrm{CDa}\end{array}$ \\
\hline 7 & $\begin{array}{l}91.52 \pm \\
0.71 \mathrm{Aa}\end{array}$ & $\begin{array}{l}87.96 \pm \\
1.36 \mathrm{ABb}\end{array}$ & $\begin{array}{l}90.96 \pm \\
\text { 0.77Aab }\end{array}$ & $\begin{array}{l}6.14 \pm \\
0.02 \mathrm{ABa}\end{array}$ & $\begin{array}{l}4.32 \pm \\
0.14 \mathrm{Bb}\end{array}$ & $0.81 \pm 0.11 \mathrm{Ec}$ & $\begin{array}{l}9.41 \pm \\
0.67 \mathrm{Gc}\end{array}$ & $\begin{array}{l}27.76 \pm \\
1.55 \mathrm{lb}\end{array}$ & $\begin{array}{l}90.30 \pm \\
1.58 \mathrm{CDa}\end{array}$ \\
\hline 8 & $\begin{array}{l}91.44 \pm \\
1.13 \mathrm{Aa}\end{array}$ & $\begin{array}{l}86.23 \pm \\
1.71 \mathrm{Bb}\end{array}$ & $\begin{array}{l}91.90 \pm \\
0.42 \mathrm{Aa}\end{array}$ & $\begin{array}{l}6.52 \pm \\
0.15 \mathrm{Aa}\end{array}$ & $\begin{array}{l}4.68 \pm \\
0.14 \mathrm{Bb}\end{array}$ & $0.68 \pm 0.15 \mathrm{Fc}$ & $\begin{array}{l}8.83 \pm \\
1.79 G \mathrm{G}\end{array}$ & $\begin{array}{l}25.94 \pm 2.58 \\
\mathrm{lb}\end{array}$ & $80.71 \pm 2.32 \mathrm{Ea}$ \\
\hline 9 & $\begin{array}{l}88.03 \pm \\
1.05 \mathrm{Aa}\end{array}$ & $85.25 \pm 1.20 \mathrm{Ba}$ & $\begin{array}{l}72.53 \pm \\
1.34 \mathrm{Bb}\end{array}$ & $\begin{array}{l}6.11 \pm \\
0.03 \mathrm{ABa}\end{array}$ & $\begin{array}{l}5.87 \pm \\
0.10 \mathrm{Aa}\end{array}$ & $\begin{array}{l}0.42 \pm \\
0.05 \mathrm{~Gb}\end{array}$ & $\begin{array}{l}2.68 \pm \\
0.98 \mathrm{HC}\end{array}$ & $\begin{array}{l}25.14 \pm 2.98 \\
\text { la }\end{array}$ & $\begin{array}{l}17.07 \pm \\
2.18 \mathrm{Fb}\end{array}$ \\
\hline
\end{tabular}

Means \pm SE sharing the same capital letters in the same columns, and same small letters in the rows are statistically insignificant $(P \geq 0.05)$

Developmental period The effect of cold exposure on the total developmental period of the parasitoid was significantly $(P=0.000)$ prolonged in case of $4{ }^{\circ} \mathrm{C}$ than the control and the 2 other temperatures (Table 8 (b)). Occasionally, from the pupae stored at $10{ }^{\circ} \mathrm{C}$, adult emergence occurred during the period of storage before being transferred to the standard condition of $25{ }^{\circ} \mathrm{C}$, usually when storage was $\geq 7$ weeks. The mean developmental period after storage of pupae at $4{ }^{\circ} \mathrm{C}$ lasted about (5.23 days), followed by $7{ }^{\circ} \mathrm{C}$ with ( 3.83 days), while at 10 ${ }^{\circ} \mathrm{C}$, it was faster (1.40 days) than the control (3.79 days). The developmental period varied significantly $(P \leq 0.05)$ with temperatures (LSD $=0.083, F=3084.431$ ), storage periods $(\mathrm{LSD}=0.144, F=66.264)$, and their interactions $(\mathrm{LSD}=0.25, F=217.805)$.

Adults' emergence percentage Throughout the 3 storage temperatures, the emergence rate decreased $(P=0.000)$ with increasing the cold exposure period but with different values in all treatments (Table 8 (c)). Compared to the control group (97.07\%), the emergence percentage was similar during the first 2 weeks of storage at $4{ }^{\circ} \mathrm{C}$; then, it declined sharply $(P=0.0001)$. At $7{ }^{\circ} \mathrm{C}$, the percentage of emerged adults was significantly decreased $(P \leq 0.01)$ up to the $9^{\text {th }}$ week $(25.13 \%)$ of storage. Furthermore, when the parasitoid pupae were stored at $10{ }^{\circ} \mathrm{C}$, they continued to emerge with high numbers up to the $8^{\text {th }}$ week $(>80 \%)$. Afterwards, the majority of emerged adults $(>85 \%)$ was deformed. There were significant differences $(P \leq 0.05)$ for the effect of temperatures, storage periods, and also storage periodtemperature interactions in adult emergence percentage $(\mathrm{LSD}=8.697, F=14.473 ; \mathrm{LSD}=15.064, F=12.223$; and $\mathrm{LSD}=26.092, F=3.281$, respectively).

\section{$F_{1}$ progeny}

Parasitism rate With prolonged storage period of parental generation, the parasitism rate in the following progeny declined significantly $(P=0.000)$ in all tested temperatures (Table $9(\mathrm{a})$ ). The parasitism percentage occurred at female's parasitoid emerged from the storage at $4{ }^{\circ} \mathrm{C}$ during the $1^{\text {st }}$ week $(92.95 \%)$ was similar to the control (92.88\%); then, it began to decrease significantly $(P \leq 0.045)$ till 7 weeks of storage. Afterwards, the $T$. bactrae adult failed to parasitize any eggs. Although the adult parasitoids emerged after cold exposure at $7{ }^{\circ} \mathrm{C}$ was low, the parasitism rate in $\mathrm{F}_{1}$ progeny was great and increased significantly $(P=0.001)$ during 2 weeks of storage; afterward, it was almost similar to the control up to 5 weeks. In case of $10{ }^{\circ} \mathrm{C}$, the parasitism rate was not influenced negatively $(P=0.716)$ by cold exposure for 4 weeks; then, the percent declined significantly $(P=$ $0.0000)$ till the $8^{\text {th }}$ week. After 9 weeks of parents' storage, the performances of adult females were affected and completely failed to parasitize eggs. The effects of temperature, storage period, and storage periodtemperature interaction in percentage of parasitized eggs were significantly different at $P \leq 0.05$ (LSD $=1.582, F=$ 
Table 9 Percentages of parasitism and adults' emergence of Trichogrammatoidea bactrae in $\mathrm{F}_{1}$ progeny during storage of parasitoid pupae at different low temperatures

\begin{tabular}{|c|c|c|c|c|c|c|}
\hline \multirow{2}{*}{$\begin{array}{l}\text { Storage } \\
\text { period } \\
\text { (weeks) }\end{array}$} & \multicolumn{3}{|l|}{ (a) Parasitism \% } & \multicolumn{3}{|c|}{ (b) Adults' emergence \% } \\
\hline & $4^{\circ} \mathrm{C}$ & $7^{\circ} \mathrm{C}$ & $10^{\circ} \mathrm{C}$ & $4^{\circ} \mathrm{C}$ & $7^{\circ} \mathrm{C}$ & $10^{\circ} \mathrm{C}$ \\
\hline Control & $92.88 \pm 0.45 A B C$ & & & $96.82 \pm 0.72 \mathrm{~A}$ & & \\
\hline 1 & $92.95 \pm 0.58 \mathrm{Ab}$ & $96.76 \pm 0.79 \mathrm{Aa}$ & $95.83 \pm 0.38 \mathrm{Aa}$ & $84.43 \pm 1.99 \mathrm{Cb}$ & $93.76 \pm 1.16 \mathrm{ABa}$ & $92.85 \pm 0.92 \mathrm{BCa}$ \\
\hline 2 & $90.93 \pm 0.74 \mathrm{Bb}$ & $94.13 \pm 0.39 \mathrm{ABa}$ & $90.43 \pm 0.58 \mathrm{Cb}$ & $91.03 \pm 1.07 \mathrm{Bb}$ & $92.08 \pm 1.03 \mathrm{Bab}$ & $94.71 \pm 1.15 \mathrm{ABa}$ \\
\hline 3 & $82.86 \pm 0.64 \mathrm{Db}$ & $91.39 \pm 1.19 \mathrm{Ca}$ & $91.28 \pm 1.06 \mathrm{Ba}$ & $90.15 \pm 1.79 \mathrm{Ba}$ & $93.78 \pm 1.80 \mathrm{ABa}$ & $93.94 \pm 0.40 \mathrm{ABa}$ \\
\hline 4 & $87.49 \pm 1.65 \mathrm{Cb}$ & $89.87 \pm 0.41 \mathrm{Cb}$ & $92.95 \pm 0.96 \mathrm{Ba}$ & $91.71 \pm 1.18 \mathrm{Bb}$ & $96.24 \pm 0.83 \mathrm{Aa}$ & $96.02 \pm 1.49 \mathrm{Aa}$ \\
\hline 5 & $82.14 \pm 1.25 \mathrm{Da}$ & $92.67 \pm 1.16 \mathrm{Ba}$ & $87.41 \pm 0.75 \mathrm{Db}$ & $83.64 \pm 1.51 \mathrm{Cb}$ & $97.13 \pm 0.46 \mathrm{Aa}$ & $96.17 \pm 0.79 \mathrm{Aa}$ \\
\hline 6 & $56.48 \pm 4.53 \mathrm{EC}$ & $73.68 \pm 3.14 \mathrm{Db}$ & $68.04 \pm 2.81 \mathrm{~Eb}$ & $96.22 \pm 0.54 \mathrm{Aa}$ & $83.37 \pm 2.33 \mathrm{Dc}$ & $88.81 \pm 1.77 \mathrm{Cb}$ \\
\hline 7 & $33.17 \pm 2.03 \mathrm{Fc}$ & $66.17 \pm 3.45 \mathrm{Ea}$ & $54.40 \pm 1.51 \mathrm{Fb}$ & $97.92 \pm 0.62 \mathrm{Aa}$ & $94.06 \pm 1.05 \mathrm{Ab}$ & $92.76 \pm 0.77 \mathrm{BCb}$ \\
\hline 8 & - & $66.14 \pm 2.93 \mathrm{Ea}$ & $13.48 \pm 0.51 \mathrm{~Gb}$ & - & $89.58 \pm 1.23 \mathrm{Ca}$ & $80.83 \pm 2.36 \mathrm{Db}$ \\
\hline 9 & - & $49.70 \pm 5.35 F$ & - & - & $96.26 \pm 1.25 \mathrm{~A}$ & - \\
\hline
\end{tabular}

Means \pm SE sharing the same capital letters in the same columns, and same small letters in the rows are statistically insignificant $(P \geq 0.05)$

201.705; LSD $=2.74, F=560.328$; and $\mathrm{LSD}=4.746, F=$ 61.161, respectively).

Adults' emergence percentage High numbers of emerged adults in $F_{1}$ were observed during all storage periods on different temperatures and did not change significantly in 7 and $10{ }^{\circ} \mathrm{C}$, reaching the highest value (> 96\%) in the $5^{\text {th }}$ week. At $4{ }^{\circ} \mathrm{C}$, the mean emergence of parasitoid was $88.19 \%$ throughout the first 5 weeks and decreased significantly $(P=0.000)$ than the control (96.82). Temperature (A), storage duration (B), and their interaction $(\mathrm{A} \times \mathrm{B})$ did not affect negatively the adult emergence percentage of parasitoid in $\mathrm{F}_{1}$ at $P \leq 0.05$.

Percentage of female adults The majority of adults' emergency in the parental generation was strongly female-biased in all treatments (Table 10 (a)). The mean percentage of females emerged from storage at 4 and 10 ${ }^{\circ} \mathrm{C}$ was non-significantly different $(P=0.624)$, while a significant difference $(P=0.000)$ was recorded between $7^{\circ}$ and the 2 other temperatures. In addition, the percentage of females in progeny was significantly different $(P=0.000)$ from control in all storage temperatures and exposure periods (Table 10 (b)). The general mean of female percentage in $\mathrm{F}_{1}$ was non-significantly $(P \geq 0.50)$ changed than the parents at all tested temperatures. Generally, it was noticeable that $10{ }^{\circ} \mathrm{C}$ gave the highest percentage of females, followed by $7{ }^{\circ} \mathrm{C}$, while $4{ }^{\circ} \mathrm{C}$ had the lowest one. Statistically, there were significant variations $(P \leq 0.05)$ in the effect of temperatures, storage periods, and their interactions on females percentage in parent $(\mathrm{LSD}=1.248, F=537.36 ; \mathrm{LSD}=2.162, F=$ 51.922; and LSD $=3.745, F=11.299$, respectively) and $\mathrm{F}_{1}$ progeny $(\mathrm{LSD}=1.112, F=244.265 ; \mathrm{LSD}=1.927, F=$ 248.712; and LSD $=3.337, F=232.102$, respectively).
Longevity of adults Fed adult parasitoids significantly $(P=0.000)$ lived much longer than un-fed ones at all tested temperatures and cold storage periods in both generations (parent and $F_{1}$ progeny) (Fig. 3). Cold storage at 4 and $10{ }^{\circ} \mathrm{C}$ occurred in parental generation did not influence negatively $(P>0.5)$ on the mean of adults survival in $F_{1}$ in both fed and un-fed adults. However, in case of $7{ }^{\circ} \mathrm{C}$, the parasitoid longevity in $\mathrm{F}_{1}$ increased significantly $(P=0.001,0.000)$ in both fed and starved ones as compared with parents, respectively. Moreover, the highest longevity was verified when parasitoids were stored at $10{ }^{\circ} \mathrm{C}$, regardless to whether supplied with food or not, followed by 4 and then $7{ }^{\circ} \mathrm{C}$. The effect of temperature $(\mathrm{A})$, storage duration $(\mathrm{B})$, and their interaction $(\mathrm{A} \times \mathrm{B})$ had significant variation on longevity of fed adults in the parental generation only at $P \leq 0.05$ $\left(\mathrm{LSD}_{(\mathrm{A})}=0.465, F=4.996 ; \mathrm{LSD}_{(\mathrm{B})}=0.805, F=7.833\right.$; $\left.\operatorname{LSD}_{(\mathrm{A} \times \mathrm{B})}=1.395, F=4.035\right)$. For un-fed adults, all the main effects and their interactions proved to be significant in the parental generation and the subsequent one at $P \leq 0.05\left(\mathrm{LSD}_{(\mathrm{A})}=0.16, F=36.999 ; \mathrm{LSD}_{(\mathrm{B})}=0.277, F\right.$ $=15.846 ; \operatorname{LSD}_{(\mathrm{A} \times \mathrm{B})}=0.48, F=6.737$ and $\operatorname{LSD}_{(\mathrm{A})}=$ $\left.0.243, F=12.72 ; \operatorname{LSD}_{(\mathrm{B})}=0.422, F=19.767 ; \operatorname{LSD}_{(\mathrm{A}} \times \mathrm{B}\right)$ $=0.73, F=9.737$, respectively).

In essence, when the parasitoid was subjected to low temperature $\left(4,7\right.$, and $\left.10{ }^{\circ} \mathrm{C}\right)$ during its immature developmental stages (larvae, pre-pupae, and pupae), the percentage of parasitism, adult emergence, and longevity of emerged adults (whether fed or un-fed) increased with the increase of storage temperature but decreased as the exposure period prolonged. These results are somewhat similar with the results reported by other researchers on different Trichogramma species (Tezze and Botto 2004; Rundle et al. 2004; Özder and Sağlam 2004; Yilmaz et al. 2007; Nadeem et al. 2010; Gharbi 2014; Bhargavi and Naik 2015; Rahimi-Kaldeh et al. 2017; Vigneswaran et al. 
Table 10 Percentages of Trichogrammatoidea bactrae females in parental and $F_{1}$ generations after storage of parasitoid pupae at different low temperatures

\begin{tabular}{|c|c|c|c|c|c|c|}
\hline \multirow{3}{*}{$\begin{array}{l}\text { Storage } \\
\text { period } \\
\text { (weeks) }\end{array}$} & \multicolumn{6}{|l|}{ Females (\%) } \\
\hline & \multicolumn{3}{|c|}{ (a) Parental generation } & \multicolumn{3}{|l|}{ (b) $\mathrm{F}_{\mathbf{1}}$ progeny } \\
\hline & $4^{\circ} \mathrm{C}$ & $7^{\circ} \mathrm{C}$ & $10^{\circ} \mathrm{C}$ & $4^{\circ} \mathrm{C}$ & $7^{\circ} \mathrm{C}$ & $10^{\circ} \mathrm{C}$ \\
\hline Control & $86.89 \pm 0.84 A$ & & & $89.37 \pm 0.68 \mathrm{~A}$ & & \\
\hline 1 & $84.00 \pm 1.37 \mathrm{Aa}$ & $71.12 \pm 1.37 \mathrm{Cb}$ & $85.89 \pm 1.00 \mathrm{Aa}$ & $89.25 \pm 1.89 \mathrm{Aa}$ & $67.5 \pm 0.96 \mathrm{Db}$ & $90.12 \pm 1.37 \mathrm{Aa}$ \\
\hline 2 & $82.44 \pm 0.72 \mathrm{Ba}$ & $70.00 \pm 2.64 \mathrm{Cb}$ & $83.44 \pm 0.46 \mathrm{ABa}$ & $89.62 \pm 1.02 \mathrm{Aa}$ & $71.75 \pm 1.61 \mathrm{BCb}$ & $88.87 \pm 1.17 \mathrm{Aa}$ \\
\hline 3 & $81.22 \pm 0.75 \mathrm{Cab}$ & $78.12 \pm 1.52 \mathrm{Bb}$ & $82.89 \pm 0.95 \mathrm{Ba}$ & $89.50 \pm 0.80 \mathrm{Aa}$ & $74.00 \pm 0.33 B C$ & $86.00 \pm 0.27 \mathrm{Bb}$ \\
\hline 4 & $76.67 \pm 1.12 \mathrm{Db}$ & $66.75 \pm 1.47 \mathrm{Dc}$ & $79.11 \pm 0.46 \mathrm{CDa}$ & $81.50 \pm 1.03 \mathrm{Ba}$ & $69.62 \pm 1.31 \mathrm{Cc}$ & $76.37 \pm 0.92 \mathrm{Db}$ \\
\hline 5 & $81.33 \pm 0.23 \mathrm{Ca}$ & $71.25 \pm 0.36 C c$ & $79.00 \pm 1.11 \mathrm{CDb}$ & $64.00 \pm 2.72 \mathrm{Cc}$ & $71.00 \pm 0.65 \mathrm{Cb}$ & $79.37 \pm 0.62 \mathrm{Ca}$ \\
\hline 6 & $75.44 \pm 0.29 \mathrm{~Eb}$ & $70.00 \pm 0.00 C D c$ & $80.00 \pm 0.41 \mathrm{Ca}$ & $58.75 \pm 1.42 \mathrm{Db}$ & $71.87 \pm 0.85 \mathrm{BCa}$ & $76.62 \pm 2.07 \mathrm{Da}$ \\
\hline 7 & $81.33 \pm 0.32 \mathrm{Ca}$ & $66.75 \pm 3.25 \mathrm{Dc}$ & $80.11 \pm 0.41 \mathrm{Cb}$ & $51.50 \pm 0.42 \mathrm{Ec}$ & $71.25 \pm 1.30 \mathrm{Cb}$ & $80.25 \pm 1.36 \mathrm{Ca}$ \\
\hline 8 & $78.33 \pm 1.23 \mathrm{Da}$ & $65.12 \pm 3.31 \mathrm{DEb}$ & $77.89 \pm 0.88 \mathrm{Da}$ & - & $71.37 \pm 0.62 \mathrm{Cb}$ & $86.87 \pm 0.29 \mathrm{Ba}$ \\
\hline 9 & $58.89 \pm 0.22 \mathrm{Fa}$ & $65.00 \pm 0.50 \mathrm{Ea}$ & $63.25 \pm 0.16 \mathrm{~Eb}$ & - & $57.87 \pm 1.90 \mathrm{E}$ & - \\
\hline
\end{tabular}

Means \pm SE sharing the same capital letters in the same columns, and same small letters in the rows are statistically insignificant $(P \geq 0.05)$

2017; Ghosh and Ballal 2018; Lü et al. 2019; and Abbes et al. 2020). In addition, the majority of adult emergency in the generation exposed to storage and the subsequent one $\left(\mathrm{F}_{1}\right)$ was strongly female-biased in all treatments but with different values. This finding is important and vital in mass production for releasing the parasitoid in the field during the insect control programs, and it proved that low temperature exposure did not affect the fertility and vigorous of females parasitoid. Contrary to the obtained observations, in some cases, a shift towards producing higher proportion of males has been reported after cold exposure, suggesting a differential mortality of females (Riddick 2001; Farid et al. 2001; Chen et al. 2008; and Abd El-Gawad et al. 2010).

It is obvious that the most suitable temperature for storage of $T$. bactrae was $10^{\circ}$, then $7{ }^{\circ} \mathrm{C}$ for a short-term in all developmental stages of the parasitoid. But, only at $10{ }^{\circ} \mathrm{C}$, larval stage could be stored for a long-term (up to 2.5 months) without much loss of performance in both parental and $F_{1}$ progeny based on the achieved results. Obtained findings are consistent with the observations recorded previously in other Trichogramma species (Rundle et al. 2004; Ma and Chen 2006; Yllmaz et al. 2007; Kim et al. 2009; Abd El-Gawad et al. 2010; Nadeem et al. 2010; Xi et al. 2013; Vigneswaran et al. 2017; and Lü et al. 2019). All of them recommended 10 ${ }^{\circ} \mathrm{C}$ as a preferable storage temperature, regardless to the developmental stage of the parasitoid subjected to the cold exposure and the storage period. In contrast, Krishnamoorthy and Mani (1999) reported that the adult parasitoid of $T$. bactrae failed to emerge from pupae stored at $7{ }^{\circ} \mathrm{C}$ for only 3 days and also for 10 days at 10

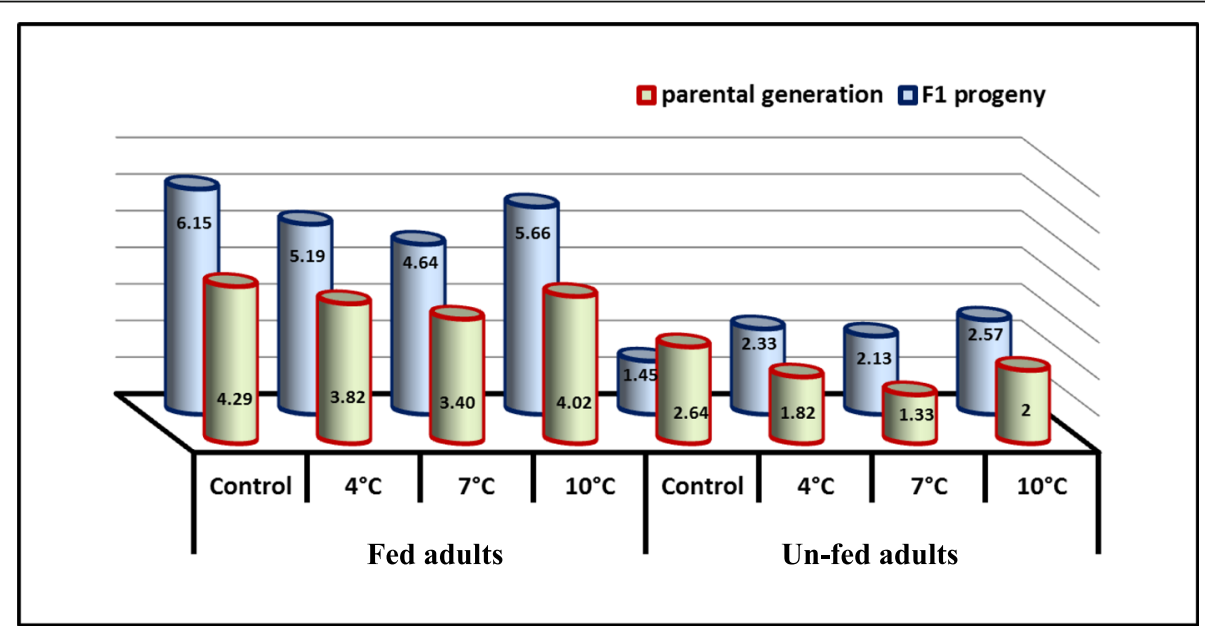

Fig. 3 Mean longevity of Trichogrammatoidea bactrae adults (fed and un-fed) of parental and $F_{1}$ progeny after storage of parasitoid pupae at different low temperatures 
${ }^{\circ} \mathrm{C}$ (Ghosh and Ballal 2018). Moreover, Geng et al. (2005) considered $10{ }^{\circ} \mathrm{C}$ was unfavorable temperature for long-term storage of $T$. dendrolimi. On the other hand, they noted the most appropriate stages for longterm storage were larval and pupal stages at $4{ }^{\circ} \mathrm{C}$, but egg and pupal stages at $7{ }^{\circ} \mathrm{C}$. However, storage parasitoid during its larval stage at $4{ }^{\circ} \mathrm{C}$ in the present study did not provide a suitable storage period more than 2 weeks only, and this may be due to the sub-lethal effect of this low temperature, and the high mortality rate was noticed. As mentioned previously by many researchers on cold storage of different Trichogramma species regardless the immature stages, Garcia et al. (2002), Özder (2008), Xi et al. (2013), Singhamuni et al. (2015), and Lü et al. (2019) showed that $\leq 5{ }^{\circ} \mathrm{C}$ seemed to be the least suitable storage temperatures. Finally, optimizing low storage temperature for this parasitic wasp is very critical for a successful mass production and field releases.

\section{Conclusion}

Obtained results proved that $T$. bactrae larvae were the most suitable immature stage to be stored for a short period ( 7 weeks) and for a long term up to ( 2.5 months) at $10{ }^{\circ} \mathrm{C}$ without much losses of their fitness in both the parental and $F_{1}$ progeny, followed by $7{ }^{\circ} \mathrm{C}$ for a short period only (4 weeks). However, cold exposure to $4{ }^{\circ} \mathrm{C}$ did not provide a suitable storage period more than 2 weeks. In addition, pre-pupae and pupae could be stored for a short period up to 4 weeks only in the all tested temperatures.

\section{Acknowledgements}

Not applicable

\section{Authors' contributions}

HOM participated in the design of this study, conducted the experiments, prepared the manuscript, and performed the statistical analysis. AHE contributed to the design of the study and revised the manuscript. Both authors read and approved the final manuscript.

\section{Funding}

This work was not supported by any funding body but personally financed.

\section{Availability of data and materials}

All data and materials are available in this manuscript.

\section{Ethics approval and consent to participate}

Not applicable

\section{Consent for publication}

Not applicable

\section{Competing interests}

The authors declare that they have no competing interests.

Received: 8 April 2020 Accepted: 23 June 2020

Published online: 06 July 2020

\section{References}

Abbes K, Zouba A, Harbi A, Chermiti B (2020) Effect of cold storage on the performance of Trichogramma bourarachae (Pintureau and Babault) (hymenoptera: Trichogrammatidae). Egypt J Biol Pest Control 30(1):1-6
Abd El-Gawad HAS, Sayed AMM, Ahmed SA (2010) Impact of cold storage temperature and period on performance of Trichogramma evanescens Westwood (hymenoptera: Trichogrammatidae). Aust J Basic Appl Sci 4(8):2188-2195

Ayvaz A, Karasu E, Karasu E, Karaborklu S, Tunçbilek AS (2008) Effects of cold storage, rearing temperature, parasitoid age and irradiation on the performance of Trichogramma evanescens Westwood (hymenoptera: Trichogrammatidae). J Stored Prod Res 44(3):232-240

Bale JS, Van Lenteren JC, Bigler F (2008) Biological control and sustainable food production. Philos Trans R Soc Lond B Sci 363(1492):761-776

Bhargavi M, Naik KV (2015) Effect of low temperature storage of trichocards parasitised by Trichogramma chilonis (Ishii) and Trichogramma japonicum (Ashmead). Asian J Bio Sci 10(1):43-47

Chen WL, Leopold RA, Harris MO (2008) Cold storage effects on maternal and progeny quality of Gonatocerus ashmeadi Girault (hymenoptera: Mymaridae). Biol Control 46(2):122-132

Colinet H, Boivin G (2011) Insect parasitoids cold storage: a comprehensive review of factors of variability and consequences. Biol Control 58(2):83-95

DeBach P, Rosen D (1991) Biological control by natural enemies CUP Archive

Denlinger DL, Lee RE Jr (1998) Physiology of cold sensitivity. In: Hallman GJ, Denlinger DL (eds) Temperature sensitivity in insects and application in integrated pest management. Westview Press, Boulder, pp 55-96

Dutton A, Bigler F (1995) Flight activity assessment of the egg parasitoid Trichogramma brassicae (Hym.: Trichogrammatidae) in laboratory and field conditions. Entomophaga 40(2):223-233

Farid A, Ullah T, Khan A, Khattak SU, Alamzeb (2001) Effect of storage at low temperature on adult eclosion and longevity of adults of Trichogramma chilonis. Pak J Zool 33(3):205-207

Fowler J, Cohen L, Jarvis P (1998) Practical statistics for field biology. Wiley, Chichester

Garcia VP, Wajnberg E, Pizzol J, Oliveira MLM (2002) Diapause in the egg parasitoid Trichogramma cordubensis: role of temperature. J Insect Physiol 48(3):349-355

Geng J, Shen Z, Li Z, Zhang F (2005) Optimal stage and temperature for cold storage of Trichogramma dendrolimi reared on Antheraea pernyi eggs. Acta Entomol Sin 48(6):903-909

Gharbi N (2014) Influences of cold storage period and rearing temperature on the biological traits of Trichogramma oleae. Tunis J Plant Prot 9(2):143-153

Ghosh E, Ballal CR (2018) Short-term storage of the egg parasitoids, Trichogramma and Trichogrammatoidea. Egypt J Biol Pest Control 28(1):34 Hutchison WD, Moratorio M, Martin JM (1990) Morphology and biology of Trichogrammatoidea bactrae (hymenoptera: Trichogrammatidae), imported from Australia as a parasitoid of pink bollworm (Lepidoptera: Gelechiidae) eggs. Ann Entomol Soc Am 83(1):46-54

Kim YG, Heo HJ, Kim GS, Hahm EH, Kim JW, Kang SY, Kwon KM (2009) Effect of a low temperature induced quiescence on short term storage of an egg parasitoid, Trichogramma sp. Nabis101. Korean J Appl Entomol 48(3):369-375

Krishnamoorthy A, Mani M (1999) Effect of low temperatures on the development and survival of Trichogrammatoidea bactrae Nagaraja. Insect Environ 5(2):78

Lü X, Han S, Li J, Liu J, Li Z (2019) Effects of cold storage on the quality of Trichogramma dendrolimi Matsumura (hymenoptera: Trichogrammatidae) reared on artificial medium. Pest Manag Sci 75(5):1328-1338

Ma CS, Chen YW (2006) Effects of constant temperature, exposure period, and age on diapause induction in Trichogramma dendrolimi. Biol Control 36(3):267-273

Nadeem S, Ashfaq M, Hamed M, Ahmed S (2010) Optimization of short and long term storage duration for Trichogramma chilonis (Ishii) (hymenoptera: Trichogrammatidae) at low temperatures. Pak J Zool 42(1):63-67

Nagaraja H (1978) Studies on Trichogrammatoidea (hymenoptera: Trichogrammatidae). Orient Insects 12(4):489-529

Özder N (2008) Effect of cold storage of adult Trichogramma brassicae, T. cacoeciae and T. evanescens (hymenoptera: Trichogrammatidae). Arch Phytopath Plant Protect 41(4):296-299

Özder N, Sağlam O (2004) Effect of short-term cold storage on the quality of Trichogramma brassicae, T. cacoeciae and T. evanescens (hymenoptera: Trichogrammatidae). Great Lakes Entomol 37(3/4):183-187

Pintureau B, Daumal J (1995) Effects of diapause and host species on some morphometric characters in Trichogramma (Hym.: Trichogrammatidae). Experientia 51(1):67-72

Rahimi-Kaldeh S, Ashouri A, Bandani A (2017) Long-term storage of sexual and asexual Trichogramma brassicae (hymenoptera: Trichogrammatidae). Biocontrol Sci Tech 27(11):1339-1347 
Riddick EW (2001) Effect of cold storage on emergence, longevity, fertility, and survival of Cotesia marginiventris (hymenoptera: Braconidae). J Entomol Sci 36(4):366-379

Rundle BJ, Thomson LJ, Hoffmann AA (2004) Effects of cold storage on field and laboratory performance of Trichogramma carverae (hymenoptera: Trichogrammatidae) and the response of three Trichogramma spp. (T. carverae, T. nr. brassicae and T. funiculatum) to cold. J Econ Entomol 97(2): 213-221

Singhamuni SAA, Hemachandra KS, Sirisena UGAI (2015) Potential for mass rearing of the egg parasitoids, Trichogramma chilonis and Tricogramma achaeae (hymenoptera: Trichogrammatidae) on Corcyra cephalonica eggs. Trop Agric Res 27(1):1-12

Tezze AA, Botto EN (2004) Effect of cold storage on the quality of Trichogramma nerudai (hymenoptera: Trichogrammatidae). Biol Control 30(1):11-16

Vigneswaran S, Dharmrajsinh MJ, Pankaj SW, Tushar KB (2017) Effect of cold temperature durations on the emergence and parasitization efficiency of laboratory reared Trichogramma chilonis (Ishii). Int J Curr Microbiol App Sci 6(5):1191-1199

Xi Y, Xin-Xia F, Dun-Song L, Bao-Xin Z, Zhen-Ying W (2013) Optimal day-age and temperature for cold storage of Trichogramma chilonis (hymenoptera: Trichogrammatidae) reared on Corcyra cephalonica (Lepidoptera: Galleriidae) eggs. Acta Entomol Sin 56(9):1010-1019

Yilmaz S, Karaborklu S, Ayvaz A (2007) Effect of cold temperature durations on the performance of the adult Trichogramma evanescens (Westwood, 1833) (hymenoptera: Trichogrammatidae). Türk Entomol Derg 31(4):269-278

\section{Publisher's Note}

Springer Nature remains neutral with regard to jurisdictional claims in published maps and institutional affiliations.

\section{Submit your manuscript to a SpringerOpen ${ }^{\circ}$ journal and benefit from:}

- Convenient online submission

- Rigorous peer review

- Open access: articles freely available online

- High visibility within the field

- Retaining the copyright to your article

Submit your next manuscript at $\boldsymbol{\nabla}$ springeropen.com 